\title{
Study on the Strengthening Mechanism of Rare Earth Ce in Magnesium Alloys, Based on First-Principle Calculations and Electronegativity Theory
}

\author{
Yanfei Chen ${ }^{1,2,3}$, Zhengqiang Zhu ${ }^{1, *}$, Jixue Zhou ${ }^{2} \mathbb{1}$ and Huasheng Lai ${ }^{3}$ \\ 1 School of Mechatronics Engineering, Nanchang University, Nanchang 330031, China; chenyf@sdas.org \\ 2 Advanced Materials Institute, Shandong Academy of Sciences, Jinan 250014, China; zhoujx@sdas.org \\ 3 Ganzhou Nonferrous Metallurgy Research Institute, Ganzhou 341400, China; songxc@sdas.org \\ * Correspondence: 350906320003@email.ncu.edu.cn
}

\section{check for}

updates

Citation: Chen, Y.; Zhu, Z.; Zhou, J.; Lai, H. Study on the Strengthening Mechanism of Rare Earth Ce in Magnesium Alloys, Based on First-Principle Calculations and Electronegativity Theory. Materials 2021, 14, 6681. https://doi.org/ $10.3390 /$ ma14216681

Academic Editors: Filippo Berto, Abílio M. P. De Jesus and José A. F. O. Correia

Received: 11 October 2021 Accepted: 1 November 2021 Published: 5 November 2021

Publisher's Note: MDPI stays neutral with regard to jurisdictional claims in published maps and institutional affiliations.

Copyright: (c) 2021 by the authors. Licensee MDPI, Basel, Switzerland. This article is an open access article distributed under the terms and conditions of the Creative Commons Attribution (CC BY) license (https:/ / creativecommons.org/licenses/by/ $4.0 /)$.

\begin{abstract}
Since the commercial applications of rare earth magnesium alloys are increasing gradually, there are considerable advantages to developing lower cost and higher performance magnesium alloys with high abundance rare earth (RE) elements. However, the alloying order of a matrix magnesium alloy is completely changed with the addition of RE elements. Therefore, further study of the strengthening mechanism of Ce element in magnesium alloys is required. In this work, the thermodynamic stability of the possible second phases in a Mg-Al-Mn-Ce multicomponent magnesium alloy were analyzed, based on first-principle calculations, and the precipitation sequence of the key RE phases was deduced as a consequence. Combined with Scanning Electron Microscope (SEM), X-ray Diffractometer (XRD), Energy Dispersive Spectrometer (EDS), and other experimental methods, it was investigated whether the preferentially precipitated second phases were the nucleation core of primary $\alpha-\mathrm{Mg}$. The complex alloying problem and strengthening mechanism in a multi-elemental magnesium alloy system were simplified with the aid of electronegativity theory. The results showed that the preferentially precipitated $\mathrm{Al}_{11} \mathrm{Ce}_{3}$ and $\mathrm{Al}_{10} \mathrm{Ce}_{2} \mathrm{Mn}_{7}$ phases could not be the nucleation core of primary $\alpha-\mathrm{Mg}$, and the grain refinement mechanism was such that the second phases at the grain boundary prevented the growth of magnesium grains. Moreover, the tensile test results showed that the reinforced structure, in which the Al-Ce phase was mixed with $\mathrm{Mg}$-Al phase, was beneficial for improving the mechanical properties of magnesium alloys, at both ambient temperature and high temperature.
\end{abstract}

Keywords: rare earth; magnesium alloy; cerium; strengthening mechanism; first principles

\section{Introduction}

Lightweight materials have become an important development direction for the transportation and aviation industries [1]. As the lightest structural material, magnesium alloys have been increasingly used to replace some traditional materials in weight-critical applications, owing to their high specific strength/specific stiffness, recyclability, rich resources, and excellent process performance [2]. However, the poor heat resistance of magnesium alloy has limited its applications in certain fields [3]. According to the viewpoints in the literature [4,5], this was caused by the poor thermal stability of the strengthening phases in magnesium alloy (such as $\mathrm{Mg}_{17} \mathrm{Al}_{12}, \mathrm{MgZn}, \mathrm{Mg}_{3} \mathrm{Sb}_{2}$, etc.), although they might perform well at ambient temperature. Pekguleryuz MO [6] suggested this was related to the activation of a slip system. As the slip system of magnesium alloy was only $\{0001\},<11 \overline{2} 0>$ at ambient temperature, but the $\{10 \overline{10}\}\{10 \overline{2} 2\}$ and $\{1010\}$ sliding surfaces were all activated when the temperature reached $250{ }^{\circ} \mathrm{C}$, which made deformation much easier. Obviously, the activation of a slip system at high temperature is inevitable; therefore, how to synthe- 
size a highly stable second phase during the smelting process, and the strengthening and toughening mechanisms of magnesium alloys, became the main directions of research $[7,8]$.

With a unique $4 \mathrm{f}$ sub-layer electronic structure, RE elements are easy to form into intermetallic compounds with a strong interatomic bonding with $\mathrm{Mg}, \mathrm{Al}, \mathrm{Mn}$, etc., which makes RE an ideal alloying element for magnesium alloys [7]. A large number of researchers have reduced the temperature sensitivity of magnesium alloys by adding rare earth elements such as $\mathrm{Y}, \mathrm{La}, \mathrm{Ce}, \mathrm{Pr}, \mathrm{Nd}, \mathrm{Gd}, \mathrm{Dy}, \mathrm{Sm}$, etc. [9], among which the most studied were $\mathrm{Mg}-\mathrm{Gd}$ and $\mathrm{Mg}-\mathrm{Y}$ series magnesium alloys [7], mainly because of their excellent aging and strengthening properties. By preparing Mg-Gd-x, Mg-Y-x ternary, or multiple alloy systems ( $x=$ Y [10-12], Sm [13,14], Nd [15], Zn [16-18], Ag [19-21], etc.), most researchers studied the structure and precipitation sequence of rare earth strengthening phases [22], explored the mechanical properties and fracture modes of samples with different heat treatments [23], and investigated the strengthening mechanism of rare earth elements in magnesium alloys [24,25].

What is certain is that, not only rare earth elements, but some conventional alloying elements (such as $\mathrm{Si}, \mathrm{Ca}, \mathrm{Sr}$, etc.) also had the effect of improving the heat resistance of magnesium alloys. For example, adding Ca element to obtain $\mathrm{Al}_{2} \mathrm{Ca}$ phase [26,27], adding Si element to form $\mathrm{Mg}_{2} \mathrm{Si}$ phase [28,29], and adding Sr element to generate $\mathrm{Al}_{4} \mathrm{Sr}$ phase $[30,31]$. All these second phases had a relatively good thermal stability, but their precipitation at the grain boundary, on the other hand, significantly inhibited the continuous distribution of $\mathrm{Mg}_{17} \mathrm{Al}_{12}$, which improved the mechanical properties and the stability of the magnesium alloys during temperature cycling [26-31]. As a matter of fact, the strengthening mechanism of the second phases formed by conventional alloying elements and by rare earth elements was basically the same. However, the interatomic bonding force of the phases formed by rare earth elements was generally much higher than that of the conventional alloying elements [3], which meant that the thermal stability was higher and could be easily verified through first-principles calculations. Therefore, in order to obtain better heat resistance, the addition of more conventional alloying elements for modification was necessary, which made problems such as poor fluidity and hot cracking more likely [32]. Some literature reports [7,33] have pointed out that rare earth elements allowed bringing some challenging scientific and industrial magnesium alloys into reality, employing various complex design strategies, especially precipitation strengthening and grain refinement, which was an effective method for the preparation of special application magnesium alloys. Nevertheless, the addition of rare earth elements always increased the raw material cost; therefore, a potential alternative was to prepare application-oriented rare earth magnesium alloys by using high-abundance and low-cost rare earth elements, such as La, Ce, Y, etc. [23].

Cerium (Ce) is one of the RE elements with the highest contents [34], and whose atomic radius is close to that of $\mathrm{Mg}$. The solid solubility of $\mathrm{Ce}$ in $\mathrm{Mg}$ was only $0.52 \%$ [35]. Therefore, the second phases formed by Ce were easily precipitated at the grain boundary, which hindered the slip of the grain boundary during deformation and effectively improved the mechanical properties and creep resistance of magnesium alloys. However, the addition of rare earth elements completely changed the alloying sequence of the matrix alloy, due to its unique physical, chemical, and electronegativity properties [36]. A large number of different types of second phases were formed as consequence [24]. Taking $\mathrm{Mg}$-Ce and AlCe binary alloys as examples, the second phases found by experimental methods included $\mathrm{MgCe}$ [37], $\mathrm{Mg}_{2} \mathrm{Ce}$ [38], $\mathrm{Mg}_{3} \mathrm{Ce}$ [39], $\mathrm{Mg}_{12} \mathrm{Ce}$ [40], $\mathrm{Mg}_{17} \mathrm{Ce}_{2}$ [40], $\mathrm{AlCe}$ [41], $\mathrm{Al}_{2} \mathrm{Ce}$ [42], $\mathrm{Al}_{3} \mathrm{Ce}$ [43], $\mathrm{Al}_{4} \mathrm{Ce}$ [25], $\mathrm{Al}_{11} \mathrm{Ce}_{3}$ [44], etc. Although transmission electron microscopy (TEM), electron probe micro analyzer (EPMA), X-ray diffraction (XRD), differential scanning calorimetry (DCS), energy dispersive spectroscopy (EDS), and other techniques were used to analyze the structure and properties of these phases, the information on the formation sequence and thermodynamic stability of the phases was still limited. It should be noted that it took extensive work to verify the effect of these precipitations on magnesium alloys by experimental methods, one by one, not to mention that the $\beta$-phase precipitation 
sequence and the strengthening mechanism of Mg-Ce based ternary or multi-elements alloys were much more complicated.

Material calculation played an important role in predicting the properties and formation laws of the second phases in multi-element alloys [45]. CALPHAD and first-principles calculations are often used to predict the phase diagram and precipitation sequence of second phases in binary or ternary magnesium alloys [37,39]. For example, Hui Zhang [46] systematically studied the formation enthalpy, phonon spectrum, elastic constant, and thermodynamic properties of $\mathrm{Mg}$-x binary alloys ( $\mathrm{x}=\mathrm{As}, \mathrm{Ba}, \mathrm{Ca}, \mathrm{Cd}, \mathrm{Cu}, \mathrm{Dy}, \mathrm{Ga}, \mathrm{Ge}, \mathrm{La}, \mathrm{Lu}, \mathrm{Ni}$, $\mathrm{Pb}, \mathrm{Sb}, \mathrm{Si}, \mathrm{Sn}$, and $\mathrm{Y}$ ) using first-principle and CALPHAD methods. In addition, the phase balances of Mg-Ca-Ce and Mg-Al-Ca ternary alloys were investigated as well, which helped to better understand the strengthening mechanism of rare earth elements. Yong Zhou [47], Z. W. Huang [48], and Zheng B [49] calculated the lattice parameters, cohesive energy, formation enthalpy, electronic structure, and elastic constant of $\mathrm{Mg}_{17} \mathrm{Al}_{12}$ [47-49], $\mathrm{Mg}_{2} \mathrm{Si}$, $\mathrm{Al}_{2} \mathrm{Y}$ [48], $\mathrm{Mg}_{2} \mathrm{Al}_{3}, \mathrm{Mg}_{2} \mathrm{Sn}, \mathrm{MgZn}_{2}, \mathrm{Mg}_{2} \mathrm{Ni}, \mathrm{Al}_{3} \mathrm{Ni}$ [49], respectively, through CASTEP code. What is more, the evolution of the second phases in Al-Ce [50,51], Al-Nd [50], Al-Y, Al-Sc, Mg-Sc [52] binary alloy, Al-Mg-RE (RE = La, Ce, Pr, Nd, Sm) [51], and Al-Mn-Ce [53-55] ternary alloy was further analyzed using CALPHAD, which was difficult to derive and verify through experiment methods. However, it was unfortunate that most of the studies did not combine the structural evolution results from experiments with the results of the thermodynamic stability calculations, to deduce the microstructure regulation mechanism of the alloy. Hence, the research efficiency could be greatly improved and relatively accurate research results could be obtained by analyzing the strengthening and toughening mechanisms of magnesium alloys with the aid of material calculations.

In this work, a method for predicting the influence mechanism of the rare earth element Ce on the solidification process of magnesium alloys was systematically proposed, based on material calculations, which employed first-principle calculations, electronegativity theory, and mismatch theory. Furthermore, the results were verified through experimental measures. This was achieved in the following way: First, an in-depth investigation on the thermodynamic stability of the possible $\mathrm{Al}-\mathrm{Ce}, \mathrm{Mg}-\mathrm{Ce}$, and $\mathrm{Mg}-\mathrm{Al}$ phases was performed with formation enthalpy, cohesive energy, and electronic structure results, and using first-principles calculations. As a result, the composition and precipitation sequences of the key rare earth phases were deduced. Then, whether the preferentially precipitated second phases were the nucleation core of the primary $\alpha-\mathrm{Mg}$ was systematically studied, based on mismatch theory, and confirmed by the microstructure, composition, and other experimental methods. The grain modification mechanism of alloys was also revealed. Third, the complex alloy reactions in Mg-Al-Zn-Mn-Ce multicomponent magnesium alloy were associated with different temperature stages in a $\mathrm{Al}-\mathrm{Ce}, \mathrm{Mg}-\mathrm{Al}$, and $\mathrm{Al}-\mathrm{Ce}-\mathrm{Mn}$ phases diagram, and simplified with the aid of electronegativity theory. Accordingly, the strengthening mechanism of Ce element in magnesium alloys was deduced and verified through tensile tests, at both ambient temperature and high temperature.

\section{Experimental and First-Principle Calculation Details}

The main purpose of this work was to study the mechanism of influence of Ce element on the solidification process of magnesium alloy. Therefore, pure magnesium, aluminum, zinc blocks, and Mg-Mn master alloy, etc. were used to prepare a matrix magnesium alloy. The compositions of the prepared matrix alloy were analyzed with a Shimadzu PDA-7000 Optical Emission Spectrometer (OES) and the results are shown in Table 1. On the basis of the matrix magnesium alloy, rare earth magnesium alloys with a Ce content of $0.2 \mathrm{wt} . \%$, 0.4 wt. $\%, 0.6$ wt. $\%, 0.8$ wt. $\%, 1$ wt. $\%$, and 3 wt. $\%$ were prepared by adding $\mathrm{Mg}-30 \mathrm{wt} . \% \mathrm{Ce}$ master alloy. The melting temperature was set at $750{ }^{\circ} \mathrm{C}$, and the protective atmosphere was a mixture of $\mathrm{CO}_{2}$ and $\mathrm{SF}_{6}$. After stirring continuously for $2 \mathrm{~min}$, the $\mathrm{Mg}$-Ce master alloy was added for $10 \mathrm{~min}$, then slagging, standing, and casting in a metal mold preheated to $200{ }^{\circ} \mathrm{C}$ were carried out to obtain an ingot with a diameter of $100 \mathrm{~mm}$. 
Table 1. Composition of the matrix magnesium alloy (wt.\%).

\begin{tabular}{cccccccc}
\hline Elements & Al & Zn & Mn & Si & Fe & Cu & Mg \\
\hline wt. $\%$ & 3.156 & 1.098 & 0.385 & 0.167 & 0.029 & 0.014 & Balance \\
\hline
\end{tabular}

The test samples were sampled from the same position of different ingots using a liner cutting machine. The microstructure of the metallographic samples was observed with a Nikon LV150NA optical microscope (OM, Nikon Instruments Inc., Melville, NY, USA) and ZEISS EVO MA 10 Scanning Electron Microscope (SEM, Carl Zeiss AG, Jena, Germany) after inlaying, grinding, polishing, and etching. The compositions were analyzed with the aid of an Oxford X-Max Energy Dispersive Spectrometer (EDS, Oxford Instruments plc, Oxford, UK) and Panalytical XPert Powder X-ray Diffractometer (XRD, PANalytical B.V, Almelo, The Netherlands), and the scan speed of XRD was set at $2{ }^{\circ} \mathrm{C} / \mathrm{min}$. For tensile tests at ambient temperature and high temperature, a Sansi CMT-5305GL type universal testing machine (Shenzhen Suns Technology Stock Co., Ltd., Shenzhen, China) was used, and the stretching rate was $2 \mathrm{~mm} / \mathrm{min}$. Micro hardness tests were performed with a HuaYing SHYCHVT-50Z type micro hardness tester (Laizhou Huayin Testing Instrument Co., Ltd., Laizhou, China) with a $1-\mathrm{Kg}$ force load applied for $10 \mathrm{~s}$, and the results were the average of 5 test points.

First-principle calculations in this work were performed using the Cambridge Sequential Total Energy Package (CASTEP) code [56], which was an implementation of the pseudopotential plane-wave method, based on density functional theory (DFT). Pseudoatomic

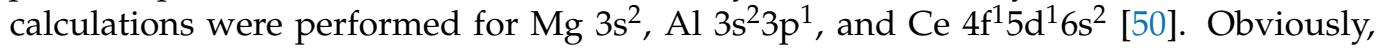
energy-level overlap occurred in Ce atoms, according to the electronic configuration, which meant that spin magnetic moments were produced by the semi-full electrons in the $4 \mathrm{f}$ and $5 \mathrm{~d}$ orbitals. Spin polarization was added and LDA+U with a Hubbard U value of $6.0 \mathrm{eV}$ was used in order to correct the calculation results $[50,57,58]$. The exchange correction functional was considered using generalized gradient approximation (GGA) with the Perdew-Burke-Eruzerhof (PBE) functional. Vanderbilt-type ultrasoft pseudo potentials were employed to describe the Coulomb interactions between the valence electrons and ionic core. The energy calculations in the first irreducible Brillouin zone were conducted with a $12 \times 12 \times 8$ k-point mesh, using a Monkhorst-Pack scheme. The cut-off energy value for the plane-wave basis set was selected as $380.0 \mathrm{eV}$. Structural optimization was carried out using Broyden-Flecher-Goldfarb-Shanno (BFGS) minimization, which was followed by calculations of total energy and electronic structure with a self-consistent field (SCF) tolerance of $1 \times 10^{-6} \mathrm{eV} /$ atom [49]. The tolerances of the geometry optimization were set as follows: the difference of the total energy within $5 \times 10^{-6} \mathrm{eV} /$ atom, maximum ionic Hellmann-Feynman force within $0.05 \mathrm{eV} / \AA$, maximum ionic displacement within $0.001 \AA$, and the maximum tress within $0.01 \mathrm{GPa}$ [57].

\section{First-Principle Calculation of the Rare Earth Phases}

In a Mg-Al-Ce ternary alloy system, second phases can be one or more of the $\mathrm{Mg}-\mathrm{Al}$ series, Mg-Ce series, or Al-Ce series. The crystal structures of the main second phases, according to the literature, are listed in Table 2; and the crystal models constructed with the structural information are shown in Figure 1. It was obvious that $\mathrm{AlCe} \mathrm{Al}_{2} \mathrm{Ce}, \mathrm{MgCe}$, $\mathrm{Mg}_{2} \mathrm{Ce}, \mathrm{Mg}_{3} \mathrm{Ce}$, and $\mathrm{Mg}_{17} \mathrm{Al}_{12}$ belonged to the cubic structure, which was $\mathrm{a}=\mathrm{b}=\mathrm{c}, \alpha=\beta=$ $\gamma=90^{\circ} ; \mathrm{Al}_{3} \mathrm{Ce}$ belonged to hexagonal structure, which was $\mathrm{a}=\mathrm{b} \neq \mathrm{c}, \alpha=\beta=90^{\circ}, \gamma=120^{\circ}$; $\mathrm{Al}_{4} \mathrm{Ce}$ belonged to the square structure, with $\mathrm{a}=\mathrm{b} \neq \mathrm{c}, \alpha=\beta=\gamma=90^{\circ} ; \mathrm{Al}_{11} \mathrm{Ce}_{3}$ belonged to the orthogonal structure, with $\mathrm{a} \neq \mathrm{b} \neq \mathrm{c}, \alpha=\beta=\gamma=90^{\circ}$; and $\mathrm{Mg}_{12} \mathrm{Ce}$ belonged to a tetragonal structure, which was $\mathrm{a}=\mathrm{b} \neq \mathrm{c}, \alpha=\beta=\gamma=90^{\circ}$. Among them, the spatial structures of $\mathrm{AlCe}$ and $\mathrm{MgCe}$, and $\mathrm{Al}_{2} \mathrm{Ce}$ and $\mathrm{Mg}_{2} \mathrm{Ce}$ were exactly the same, except that the position of the $\mathrm{Mg}$ and $\mathrm{Al}$ atoms was exchanged. 
Table 2. The possible second phases in Mg-Al-Ce ternary alloy.

\begin{tabular}{cccccc}
\hline Species & $\mathrm{AlCe}$ & $\mathrm{Al}_{2} \mathrm{Ce}$ & $\mathrm{Al}_{3} \mathrm{Ce}$ & $\mathrm{Al}_{\mathbf{4}} \mathrm{Ce}$ & $\mathrm{Al}_{11} \mathrm{Ce}_{3}$ \\
\hline Structure & $\mathrm{Pm} \overline{3} \mathrm{~m}$ & $\mathrm{Fd} \overline{3} \mathrm{~m}$ & $\mathrm{P} 63 / \mathrm{mmc}$ & $\mathrm{I} 4 / \mathrm{mmm}$ & $\mathrm{Immm}$ \\
\hline Space No. & 221 & 227 & 194 & 139 & 71 \\
\hline Species & $\mathrm{MgCe}$ & $\mathrm{Mg}_{2} \mathrm{Ce}$ & $\mathrm{Mg}_{3} \mathrm{Ce}$ & $\mathrm{Mg}_{12} \mathrm{Ce}$ & $\mathrm{Mg}_{17} \mathrm{Al}_{12}$ \\
\hline Structure & $\mathrm{Pm} \overline{3} \mathrm{~m}$ & $\mathrm{Fd} \overline{3} \mathrm{~m}$ & $\mathrm{Fm} \overline{3} \mathrm{~m}$ & $\mathrm{I} 4 / \mathrm{mmm}$ & $\overline{\mathrm{I}} 3 \mathrm{~m}$ \\
\hline Space No. & 221 & 227 & 225 & 139 & 217 \\
\hline
\end{tabular}

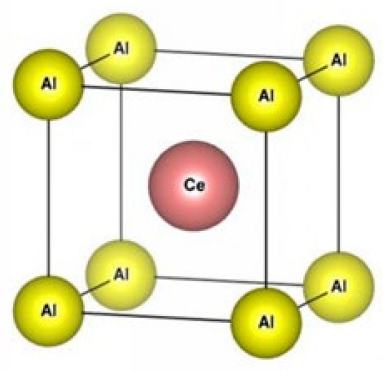

(a) $\mathrm{AlCe}$

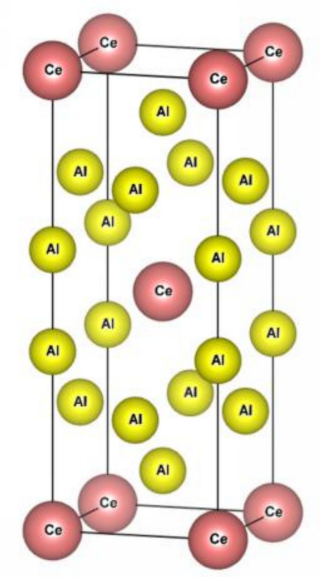

(d) $\mathrm{Al}_{4} \mathrm{Ce}$

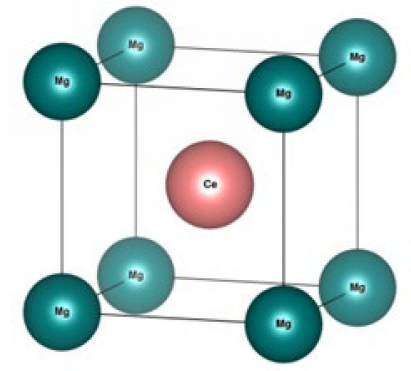

(g) $\mathrm{MgCe}$

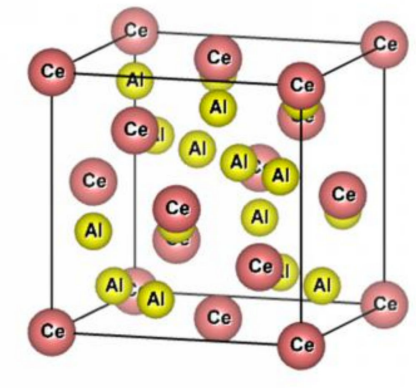

(b) $\mathrm{Al}_{2} \mathrm{Ce}$

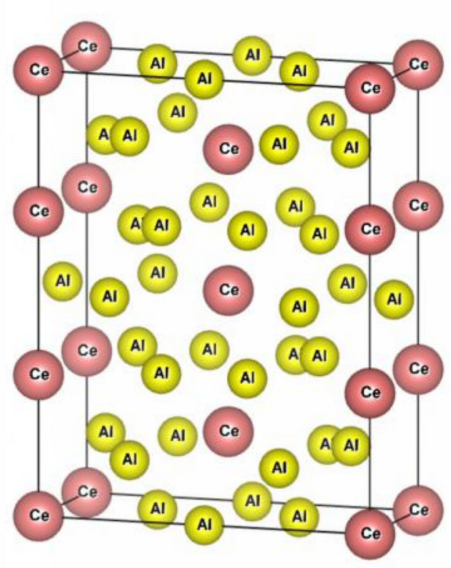

(e) $\mathrm{Al}_{11} \mathrm{Ce}_{3}$

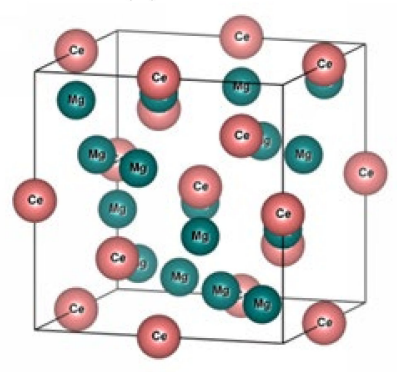

(h) $\mathrm{Mg}_{2} \mathrm{Ce}$

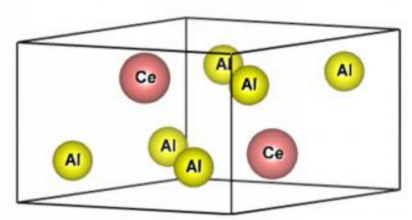

(c) $\mathrm{Al}_{3} \mathrm{Ce}$

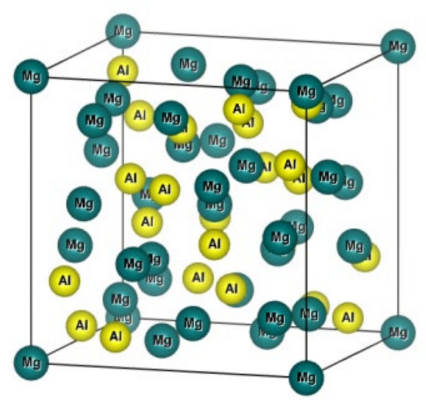

(f) $\mathrm{Mg}_{17} \mathrm{Al}_{12}$

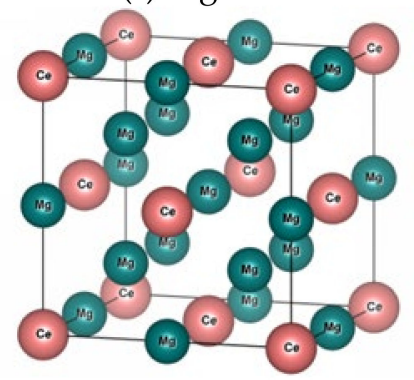

(i) $\mathrm{Mg}_{3} \mathrm{Ce}$

Figure 1. Cont. 


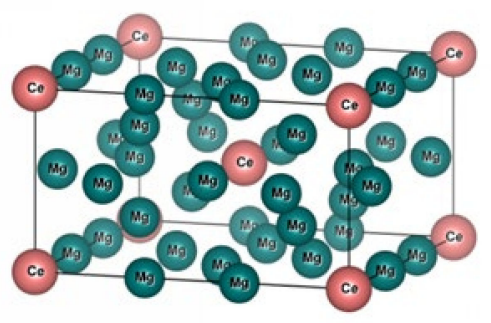

(j) $\mathrm{Mg}_{12} \mathrm{Ce}$

Figure 1. Crystal structure of the possible second phases in Mg-Al-Ce ternary alloy.

To investigate the structural stability, the cohesive energy $\left(\mathrm{E}_{\mathrm{Coh}}\right)$ and formation enthalpy $(\triangle \mathrm{H})$ were calculated. The cohesive energy was defined as the total energy released by isolated atoms combined into a solid. It was used to characterize the strength of the bond between elements, which reflected the stability of the crystal structure [8]. While, the formation enthalpy referred to the energy absorbed in the process of forming a compound with a crystal structure from a pure element solid, which was used to reflect the difficulty of the formation of a second phase [34].

$$
\begin{aligned}
\Delta H & =\frac{1}{x+y}\left(E_{\text {Total }}-x E_{\text {Solid }}^{\mathrm{A}}-y E_{\text {Solid }}^{\mathrm{B}}\right) \\
E_{\text {Coh }} & =\frac{1}{x+y}\left(E_{\text {Total }}-x E_{\text {Atom }}^{\mathrm{A}}-y E_{\text {Atom }}^{\mathrm{B}}\right)
\end{aligned}
$$

The cohesive energy and formation enthalpy were calculated as Equations (1) and (2), respectively, where $x$ and $y$ were the numbers of $A$ and $B$ atoms in the unit cell, $E_{\text {Total }}$ was the total energy of the unit cell, $\mathrm{E}^{\mathrm{A}}$ Atom and $\mathrm{E}^{\mathrm{B}}$ Atom were the energies of the atom in a free state, and $\mathrm{E}^{\mathrm{A}}$ Solid and $\mathrm{E}^{\mathrm{B}}$ Solid represented the energy of a pure element solid. A negative cohesive energy and formation enthalpy usually signified an exothermic process, and the lower the value, the stronger the stability. The results obtained through first-principle calculations are shown in Tables 3 and 4, from which the stability and precipitation order of the second phases in the Mg-Al-Ce ternary alloy were preliminarily deduced [50,57,59,60].

\begin{tabular}{|c|c|c|c|c|c|c|}
\hline Species & Mg Atom & Al Atom & Ce Atom & Mg Solid & Al Solid & Ce Solid \\
\hline $\begin{array}{c}\mathrm{E}_{\text {Atom }} / \mathrm{E}_{\text {Solid }} \\
(\mathrm{eV})\end{array}$ & -52.670 & -972.494 & -1058.339 & -56.404 & -973.949 & -1061.349 \\
\hline Cal. & $-52.738^{a}$ & $-972.226^{a}$ & $-1058.349^{b}$ & $-56.420^{a}$ & $-973.996^{\mathrm{a}}$ & $-1064.147^{b}$ \\
\hline
\end{tabular}

Table 3. The energy of atoms in a ground state and pure element solid.

\begin{tabular}{|c|c|c|c|c|c|c|c|c|c|c|}
\hline Species & AlCe & $\mathrm{Al}_{2} \mathrm{Ce}$ & $\mathrm{Al}_{3} \mathrm{Ce}$ & $\mathrm{Al}_{4} \mathrm{Ce}$ & $\mathrm{Al}_{11} \mathrm{Ce}_{3}$ & $\mathrm{MgCe}$ & $\mathrm{Mg}_{2} \mathrm{Ce}$ & $\mathrm{Mg}_{3} \mathrm{Ce}$ & $\mathrm{Mg}_{12} \mathrm{Ce}$ & $\mathrm{Mg}_{17} \mathrm{Al}_{12}$ \\
\hline$\triangle \mathrm{H}(\mathrm{eV})$ & -0.333 & -0.488 & -0.407 & -0.316 & -0.365 & -0.007 & 0.686 & -0.085 & -0.069 & -0.064 \\
\hline Cal. (eV) & $-0.337^{c}$ & $-0.462^{c}$ & $-0.424^{c}$ & $-0.302^{c}$ & $-0.359^{c}$ & $-0.010^{b}$ & $1.311^{b}$ & $-0.080^{b}$ & $-0.061^{\mathrm{e}}$ & $-0.053^{d}$ \\
\hline$E_{\mathrm{Coh}}(\mathrm{eV})$ & -3.704 & -3.981 & -3.960 & -3.906 & -3.944 & -2.239 & -1.287 & -1.928 & -1.643 & -2.462 \\
\hline Cal. (eV) & - & - & - & - & - & $-3.059^{b}$ & $-1.288^{b}$ & $-2.453^{b}$ & - & $-2.385^{d}$ \\
\hline
\end{tabular}

Table 4. $\mathrm{E}_{\mathrm{Coh}}$ and $\triangle \mathrm{H}$ of the possible second phases.

${ }^{\mathrm{b}}$ Ref. [61], ${ }^{\mathrm{c}}$ Ref. [50], ${ }^{\mathrm{d}}$ Ref. [47], ${ }^{\mathrm{e}}$ Ref. [60].

Obviously, the $\mathrm{E}_{\mathrm{Coh}}$ and $\triangle \mathrm{H}$ of the Al-Ce series phases were both negative, indicating that the $\mathrm{Al}-\mathrm{Ce}$ phase above could exist stably. Among them, $\mathrm{Al}_{2} \mathrm{Ce}$ had the largest 
$\triangle \mathrm{H}$, which was $-0.488 \mathrm{eV}$; followed by $\mathrm{Al}_{3} \mathrm{Ce}, \mathrm{Al}_{11} \mathrm{Ce}_{3}, \mathrm{AlCe}$, and $\mathrm{Al}_{4} \mathrm{Ce}$, with a $\triangle \mathrm{H}$ of $-0.407 \mathrm{eV},-0.365 \mathrm{eV},-0.333 \mathrm{eV}$, and $-0.316 \mathrm{eV}$, respectively. The results showed a good agreement with the values from the research of Wen-Jiang Ding [57] and Michael C. Gao [50]. The formation enthalpy was arranged in the order $\mathrm{Al}_{2} \mathrm{Ce}>\mathrm{Al}_{11} \mathrm{Ce}_{3}>\mathrm{Al}_{4} \mathrm{Ce}$ in Wen-Jiang Ding's research, and was expanded to $\mathrm{Al}_{2} \mathrm{Ce}>\mathrm{Al}_{3} \mathrm{Ce}>\mathrm{Al}_{11} \mathrm{Ce}_{3}>\mathrm{AlCe}>\mathrm{Al}_{4} \mathrm{Ce}$ by Michael $\mathrm{C}$. Gao. Furthermore, the cohesive energy showed the same arrangement laws as the formation enthalpy $[50,52,62]$.

In contrast, the absolute values of $\mathrm{E}_{\mathrm{Coh}}$ and the $\triangle \mathrm{H}$ of $\mathrm{Mg}$-Ce phases were significantly lower than that of the Al-Ce phases, indicating that the alloying ability and interatomic bonding of $\mathrm{Mg}$ and $\mathrm{Ce}$ elements were much lower, which was consistent with electronegativity theory. The $\triangle \mathrm{H}$ of the $\mathrm{Mg}$-Ce series phases decreased in the order $\mathrm{Mg}_{3} \mathrm{Ce}, \mathrm{Mg}_{12} \mathrm{Ce}$, and $\mathrm{MgCe}$, with the values $-0.085 \mathrm{eV},-0.069 \mathrm{eV}$, and $-0.07 \mathrm{eV}$, respectively. While the $\triangle \mathrm{H}$ of $\mathrm{Mg}_{2} \mathrm{Ce}$ was positive, which meant a difficulty in formation. In addition, the calculations showed that $\mathrm{E}_{\mathrm{Coh}}$ and $\triangle \mathrm{H}$ of the typical $\mathrm{Mg}_{17} \mathrm{Al}_{12}$ phase were negative, and the values were between those of the $\mathrm{Al}-\mathrm{Ce}$ and $\mathrm{Mg}$-Ce phases, indicating that the alloying ability between $\mathrm{Mg}$ and $\mathrm{Al}$ was lower than $\mathrm{Al}$ with $\mathrm{Ce}$, but higher than $\mathrm{Mg}$ with $\mathrm{Ce}$. A comparison of $\mathrm{E}_{\mathrm{Coh}}$ and $\triangle \mathrm{H}$ is shown in Figure 2.

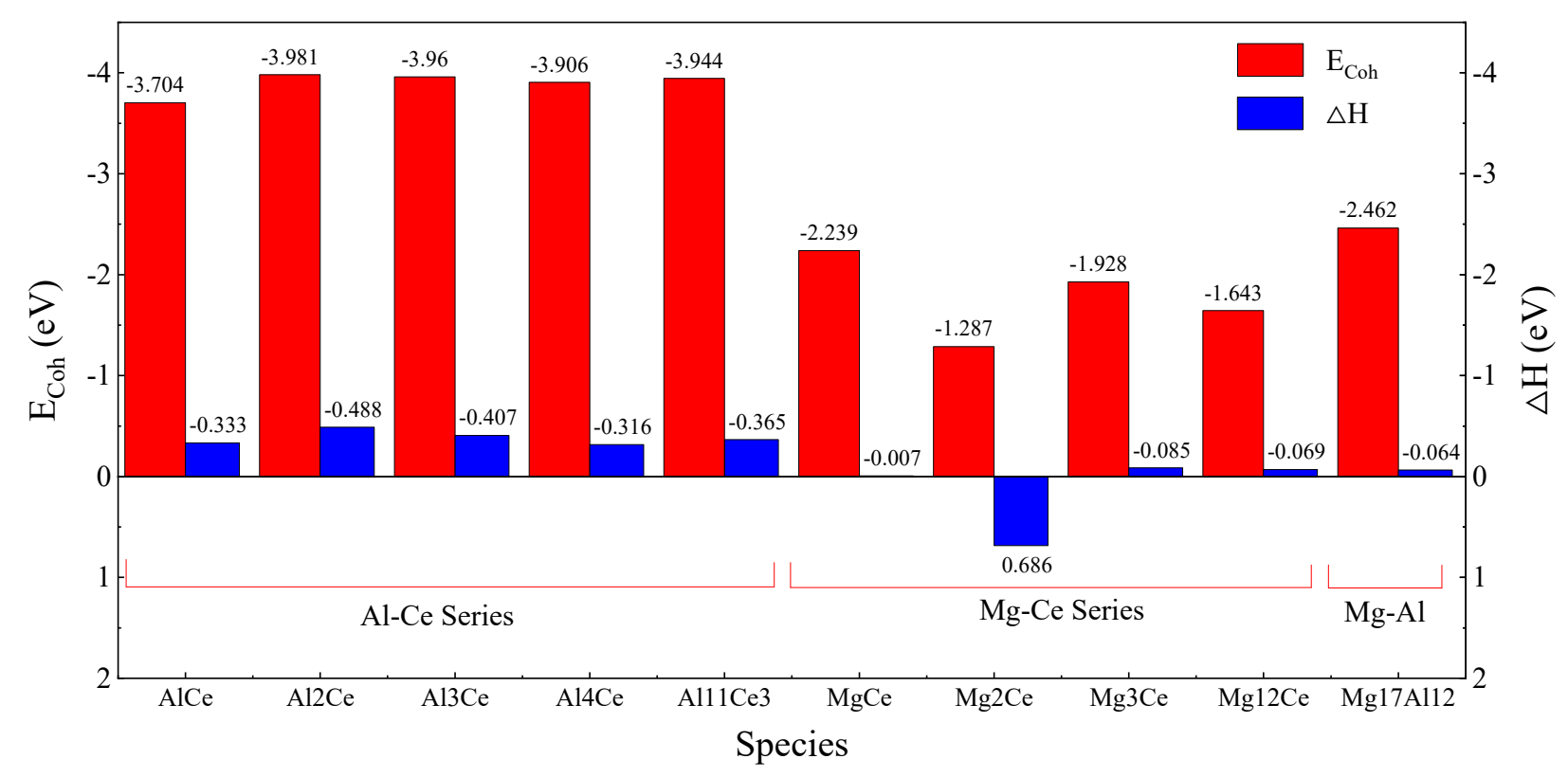

Figure 2. The contrast of $\mathrm{E}_{\mathrm{Coh}}$ and $\triangle \mathrm{H}$ among $\mathrm{Al}-\mathrm{Ce}, \mathrm{Mg}-\mathrm{Ce}$, and $\mathrm{Mg}-\mathrm{Al}$ phases.

The alloying reaction sequence of the Mg-Al-Ce ternary alloy system was deduced by comparing the $\mathrm{E}_{\mathrm{Coh}}$ and $\triangle \mathrm{H}$ results of the $\mathrm{Mg}$-Ce series, $\mathrm{Al}$-Ce series, and $\mathrm{Mg}$ - $\mathrm{Al}$ series intermediate phases. Since Ce had the strongest alloying ability, Ce was preferentially alloying with $\mathrm{Al}$ or other elements with a higher electronegativity difference (if any) to form a rare earth phase, until a certain element was exhausted. While, the remaining alloying elements reacted again, according to their alloying ability, until solidification. Combined with the addition of a small amount of $\mathrm{Al}$ (about $3 \mathrm{wt} . \%)$ and $\mathrm{Ce}(<1 \mathrm{wt} . \%)$ in this work, it could be inferred that the main precipitations of the Mg-Al-Ce ternary alloy were $\mathrm{Al}-\mathrm{Ce}$ phase and $\mathrm{Mg}$ - $\mathrm{Al}$ phase. In addition, Ce element was added in a form of $\mathrm{Mg}$-Ce master alloy at $750^{\circ} \mathrm{C}$, which obviously did not meet the formation conditions of $\mathrm{Al}_{2} \mathrm{Ce}$ and $\mathrm{Al}_{3} \mathrm{Ce}$ (analyzed detailed in Section 4.3). Moreover, the micro equilibrium system was rich in $\mathrm{Al}$; hence, the main $\mathrm{Al}-\mathrm{Ce}$ intermediate phase was $\mathrm{Al}_{11} \mathrm{Ce}_{3}$, with a formation pathway of eutectic reaction at $641{ }^{\circ} \mathrm{C}$ [63]. 


\section{Results and Discussion}

\subsection{Effect of Ce on the Microstructure and Compositions of Magnesium Alloys}

Metallographic diagrams of the matrix magnesium alloy with $\mathrm{Al}, \mathrm{Zn}, \mathrm{Mn}$, and other elements added are shown in Figure 3. It was clear that the grains of the matrix magnesium alloy were equiaxed, with a size of about $600 \mu \mathrm{m}$. The second phases mainly precipitated continuously at the grain boundary, and a small fraction precipitated in the grain with a granular shape, as shown in Figure 3a-c. When the matrix alloy samples were solution treated at $200{ }^{\circ} \mathrm{C}$ for $20 \mathrm{~h}$, the precipitated phases dissolved completely, as shown in Figure 3d. Rare earth magnesium alloys with Ce contents of $0.2 \mathrm{wt} . \%, 0.4 \mathrm{wt} . \%, 0.6 \mathrm{wt} . \%$, $0.8 \mathrm{wt} . \%, 1 \mathrm{wt} . \%$, and $3 \mathrm{wt} . \%$ (mass fraction) were prepared with this composition as a matrix in this work.

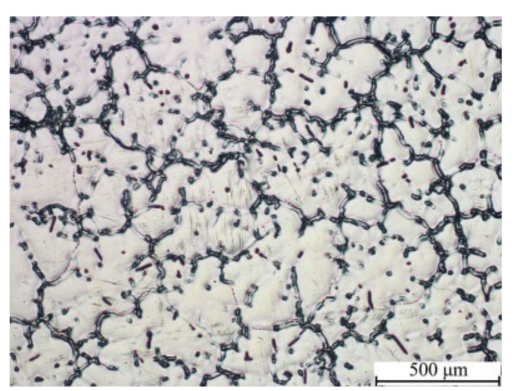

(a) matrix magnesium alloy

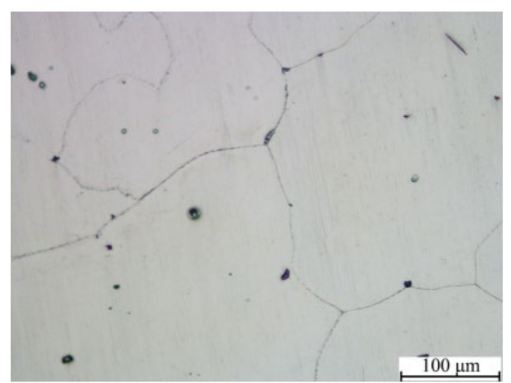

(d) solution treated sample

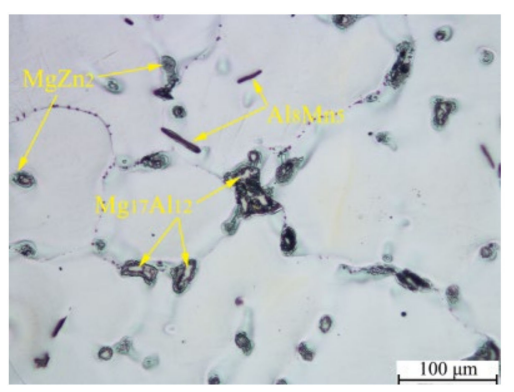

(b) precipitated phases

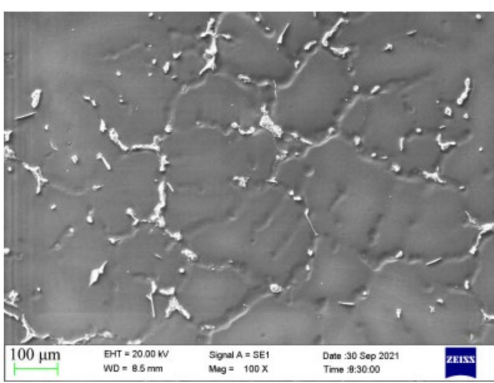

(e) SEM of the matrix alloy

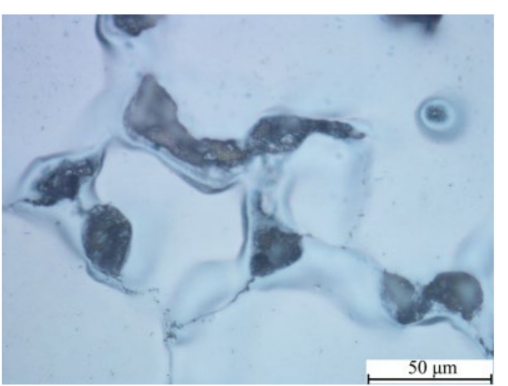

(c) morphology of the phases

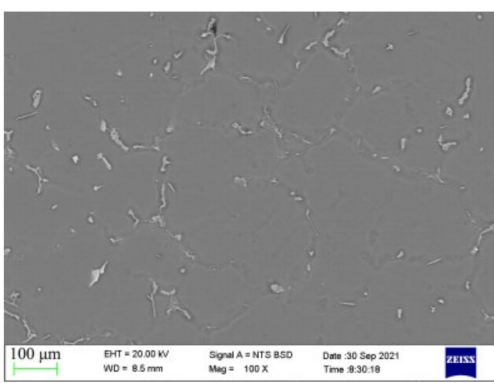

(f) BSE of the matrix alloy

Figure 3. The microstructure morphology of Mg-Al-Zn-Mn-Si matrix alloy.

The metallographic and precipitated phase morphology of magnesium alloys with $0.2-$ 3 wt.\% Ce added are shown in Figure 4. The average grain size decreased slightly to about 300-400 $\mu \mathrm{m}$, while the number of small-sized grains increased after adding $0.2-0.4 \mathrm{wt} . \%$ Ce element. However, when the addition of Ce was more than $0.6 \mathrm{wt}$ \%, the grains grew gradually, as shown in Figure $4 \mathrm{~g}, \mathrm{j}, \mathrm{m}$. What was noteworthy was that the precipitate structure changed significantly after the addition of Ce element, with a small number of needle-like precipitates appearing in the grain and grain boundary and mixed with the conventional granular precipitates. In addition, the number of needle-like precipitates rose gradually when the Ce content increased, as shown in Figure $4 b, e, h$.

The back scattered electron (BSE) in Figure 4c,f,i,l and the EDS mapping observation in Figure 5 found several kinds of precipitates with obvious differences in shape and color contrast. It was clear that the Mn element appeared together with $\mathrm{Al}$ and Ce with a rod-like morphology, which was probably Al-Mn-Ce phase. The Zn element was accompanied by $\mathrm{Al}$ in the form of a granule shape (Al-Zn phase). While, needle-like phase with a length of about $50 \mu \mathrm{m}$ was formed with $\mathrm{Al}$ and Ce elements (Al-Ce phase). 


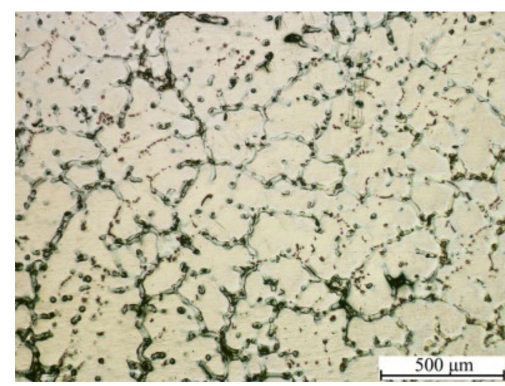

(a) 0.2 wt.\% Ce added sample

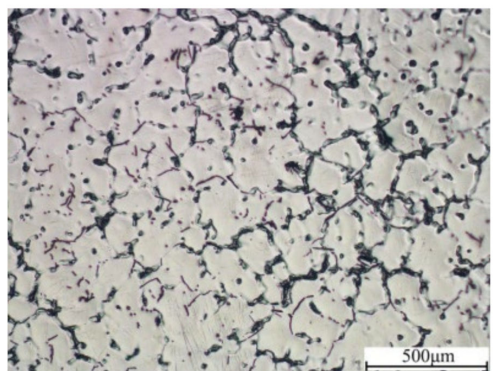

(d) 0.4 wt. $\%$ Ce added sample

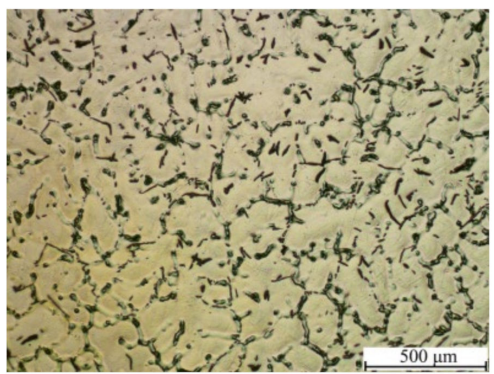

(g) 0.6 wt.\% Ce added sample

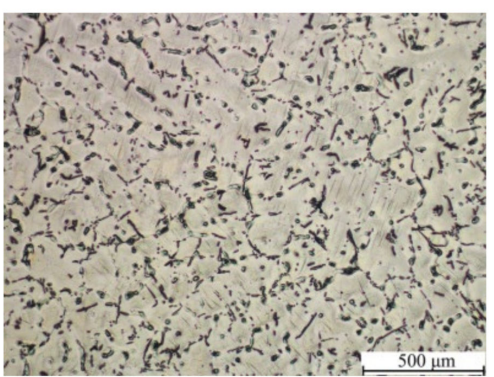

(j) 1 wt.\% Ce added sample

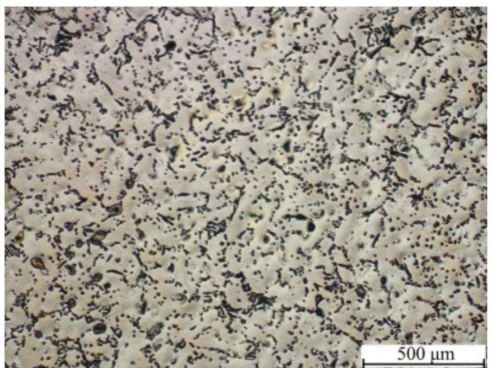

(m) 3 wt.\% Ce added sample

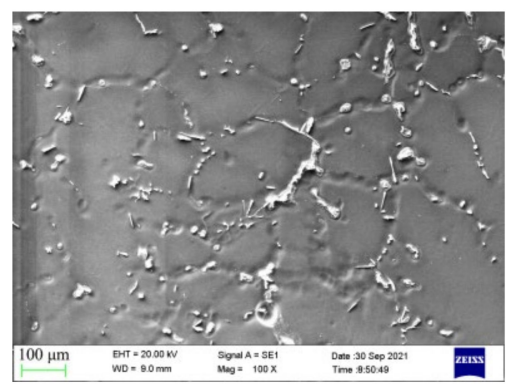

(b) SEM of 0.2 wt.\% Ce sample

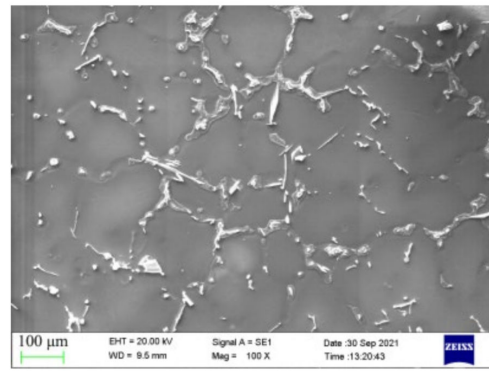

(e) SEM of 0.4 wt. $\%$ Ce sample

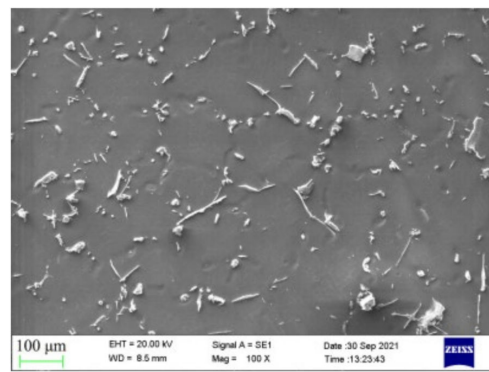

(h) SEM of 0.6 wt. \% Ce sample

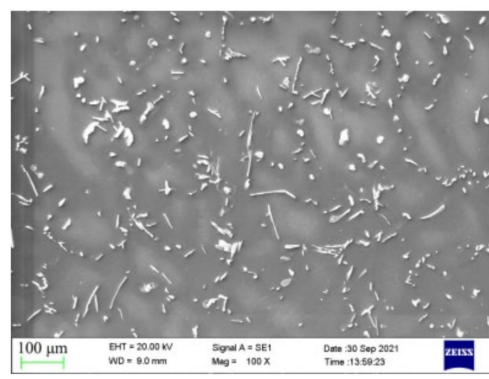

(k) SEM of 1 wt. \% Ce sample

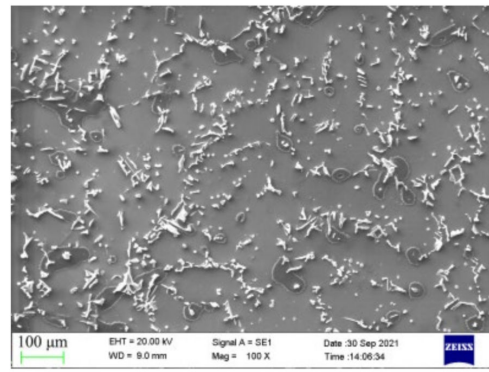

(n) SEM of 3 wt. \% Ce sample

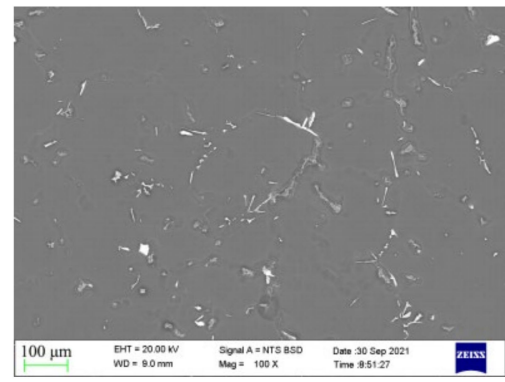

(c) BSE of 0.2 wt. \% Ce sample

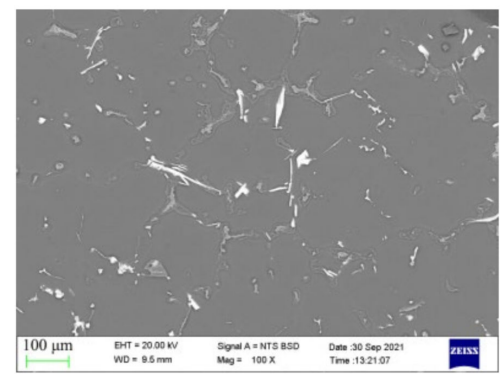

(f) BSE of 0.4 wt. $\%$ Ce sample

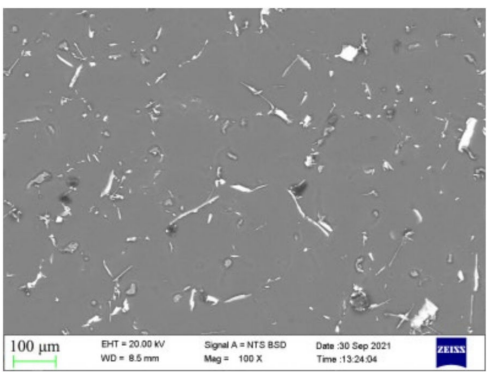

(i) BSE of 0.6 wt. $\%$ Ce sample

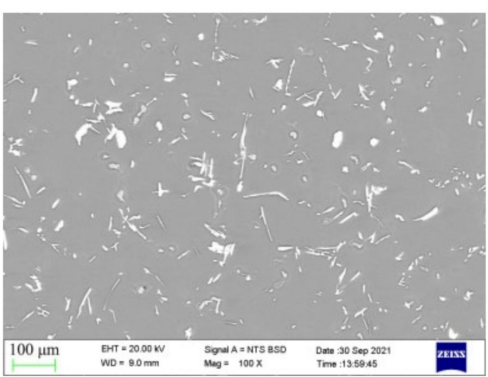

(1) BSE of 1 wt.\% Ce sample

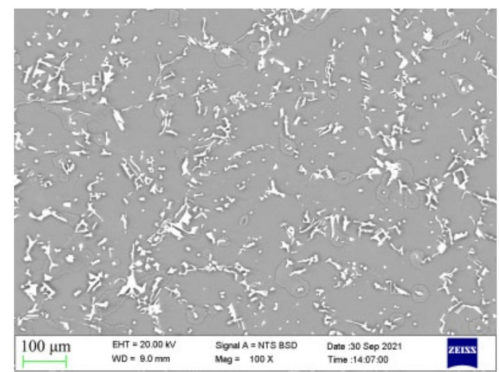

(o) BSE of 3 wt. \% Ce sample

Figure 4. Metallographic and precipitated phase diagram of samples with different Ce contents. 

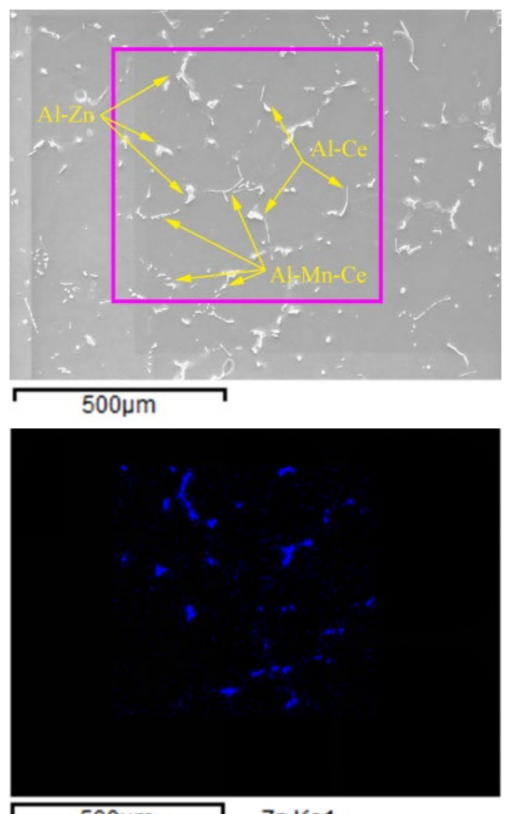

$\stackrel{500 \mu \mathrm{m}}{2 n \mathrm{Ka} 1}$

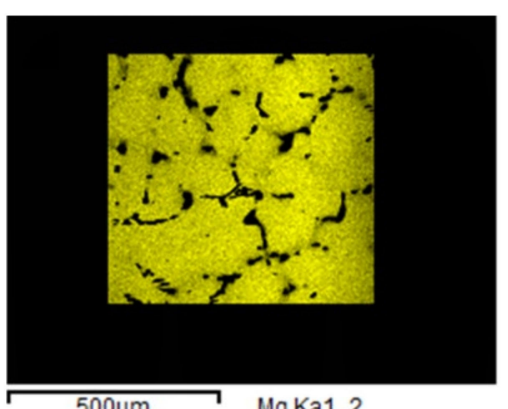

$500 \mu \mathrm{m}$

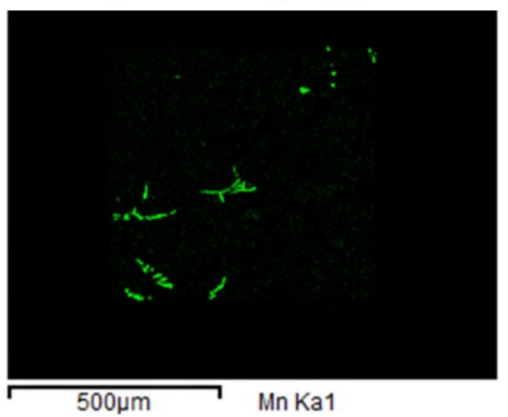

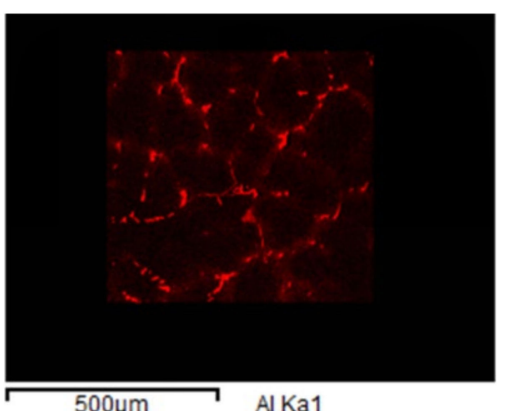

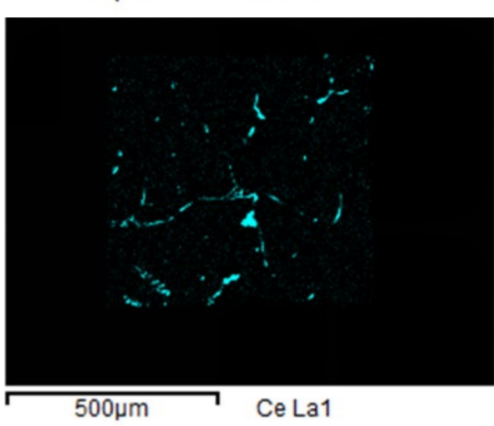

Figure 5. EDS surface scan results of the magnesium alloy with $0.2 \mathrm{wt} . \%$ Ce.

XRD was used to further analyze the compositions of the matrix alloy and samples with Ce element, and the results are shown in Figure 6. Clearly, the second phases in the matrix magnesium alloy were $\mathrm{Mg}_{17} \mathrm{Al}_{12}, \mathrm{MgZn}_{2}$, and trace $\mathrm{Al}_{8} \mathrm{Mn}_{5}$ (Figure 6a), which meant that the alloying reaction of the matrix alloy was mainly dominated by $\mathrm{Al}$ and $\mathrm{Mg}$, and supplemented by the reaction of trace elements such as Zn, Mn, and Si.
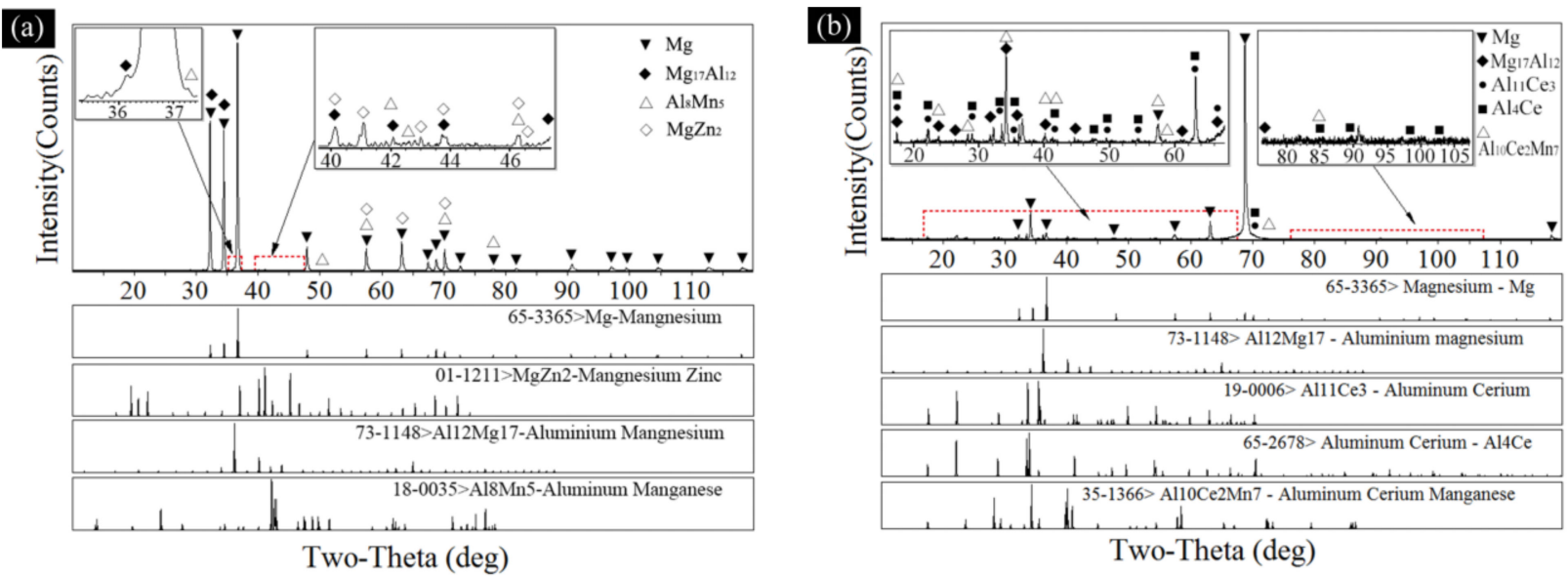

Figure 6. Composition of the alloys (a) matrix magnesium alloy (b) magnesium alloy with 0.8 wt.\% Ce.

The addition of Ce significantly changed the alloying sequence of the matrix magnesium alloy. Figure $6 \mathrm{~b}$ shows the phase composition of the sample with $0.8 \mathrm{wt} \% \mathrm{Ce}$. Combined with the EDS analysis in Figure 5, it can be seen that the $\mathrm{Mg}-\mathrm{Al}$ phase in the EDS was actually $\mathrm{Mg}_{17} \mathrm{Al}_{12}$, the $\mathrm{Al}-\mathrm{Mn}$-Ce phase was $\mathrm{Al}_{10} \mathrm{Ce}_{2} \mathrm{Mn}_{7}$, and the $\mathrm{Al}-\mathrm{Ce}$ phase was $\mathrm{Al}_{11} \mathrm{Ce}_{3}$ or $\mathrm{Al}_{4} \mathrm{Ce}$ phase. However, some trace phases were beyond the sensitivity of the XRD machine (such as Al-Zn, Mg-Si phase), which was difficult to calibrate but could be found in the EDS. The research results of Gao M C [50] showed that the $\mathrm{Al}_{11} \mathrm{Ce}_{3}$ was obtained by forming an $\mathrm{Al}$ vacancy in $\mathrm{Al}_{12} \mathrm{Ce}_{3}$ (i.e., $\mathrm{Al}_{4} \mathrm{Ce}$ ); therefore, $\mathrm{Al}_{11} \mathrm{Ce}_{3}$ and $\mathrm{Al}_{4} \mathrm{Ce}$ had a quite similar structure. Moreover, the designed differential thermal experiment (DTA) showed that $\mathrm{Al}_{11} \mathrm{Ce}_{3}$ was formed by the eutectic transformation of $\mathrm{Al}_{4} \mathrm{Ce}$ at $641{ }^{\circ} \mathrm{C}$. The 
overall reaction equation was $\mathrm{Liq} \leftrightarrow \mathrm{Al}_{11} \mathrm{Ce}_{3}+\mathrm{Al}$, which included $\mathrm{Al}_{4} \mathrm{Ce} \leftrightarrow \mathrm{Al}+\mathrm{Al}_{11} \mathrm{Ce}_{3}$. Therefore, $\mathrm{Al}_{4} \mathrm{Ce}$ was the high temperature $\beta$-phase of $\mathrm{Al}_{11} \mathrm{Ce}_{3}$, and the residue of $\mathrm{Al}_{4} \mathrm{Ce}$ was related to the solidification process. The XRD tests results showed a good agreement with the first-principle calculation results; both $\mathrm{Al}_{11} \mathrm{Ce}_{3}$ and $\mathrm{Al}_{4} \mathrm{Ce}$ could precipitate in $\mathrm{Mg}$-Al-Ce ternary alloy, but the thermal stability of $\mathrm{Al}_{4} \mathrm{Ce}$ was not as good as $\mathrm{Al}_{11} \mathrm{Ce}_{3}$.

According to the electronegativity theory proposed by Linus Carl Pauling [64], the electronegativities of $\mathrm{Mg}, \mathrm{Al}, \mathrm{Zn}, \mathrm{Mn}$, and Ce were 1.293, 1.613, 1.59, 1.75, and 1.12, respectively. Obviously, the electronegativity difference between Ce and Mn was the largest, followed by $\mathrm{Ce}-\mathrm{Al}, \mathrm{Ce}-\mathrm{Zn}$, and $\mathrm{Ce}-\mathrm{Mg}$. Therefore, after the addition of $\mathrm{Ce}$ to the $\mathrm{Mg}-\mathrm{Al}-\mathrm{Zn}-\mathrm{Mn}$ multi-elements system, Ce first alloyed with $\mathrm{Mn}$, then with $\mathrm{Al}, \mathrm{Zn}$, and other elements, to form a rare earth phase, due to the electronegativity. Since the content of $\mathrm{Mn}$ in the matrix magnesium alloy was relatively low, only a small amount of $\mathrm{Al}_{10} \mathrm{Ce}_{2} \mathrm{Mn}_{7}$ phase was formed, preferentially with the depletion of Mn. An excess of Ce element alloying with $\mathrm{Al}$ and $\mathrm{Al}_{11} \mathrm{Ce}_{3}$ was formed as a result. Finally, the typical $\mathrm{Mg}_{17} \mathrm{Al}_{12}$ was formed by the remaining $\mathrm{Al}$ and $\mathrm{Mg}$ elements at about $436{ }^{\circ} \mathrm{C}$, when the magnesium alloy had partially solidified. However, since the melting point of the $\mathrm{Al}_{10} \mathrm{Ce}_{2} \mathrm{Mn}_{7}$ phase was about $1150{ }^{\circ} \mathrm{C}[43,55]$ and its formation temperature was $700{ }^{\circ} \mathrm{C}$, the magnesium alloy was still in liquid state [43] (see Section 4.3). Therefore, the formed $\mathrm{Al}_{10} \mathrm{Ce}_{2} \mathrm{Mn}_{7}$ phase floated or precipitated in liquid alloy, which could be removed by slag removal. The morphology and EDS results of the sample with 3 wt.\% Ce are shown in Figure 7, it is clear that the precipitated phases became singular after slag removal; even though a large amount of rare earth elements were added at $750{ }^{\circ} \mathrm{C}$, most of the precipitates were $\mathrm{Al}_{11} \mathrm{Ce}_{3}$ phases and only a small amount of other phases, such as $\mathrm{Al}-\mathrm{Zn}$, were detected. This analysis was verified by the EDS composition test results and was highly consistent with electronegativity theory and the first-principle calculations in the previous section.

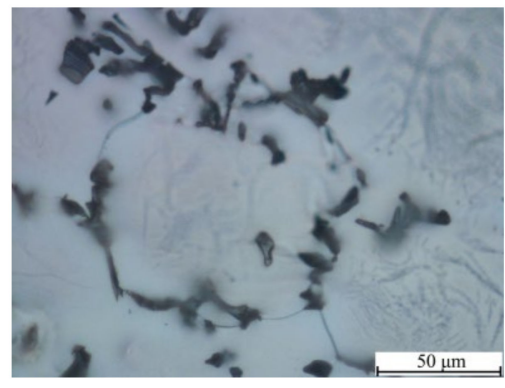

(a) OM of 3 wt. \% Ce sample

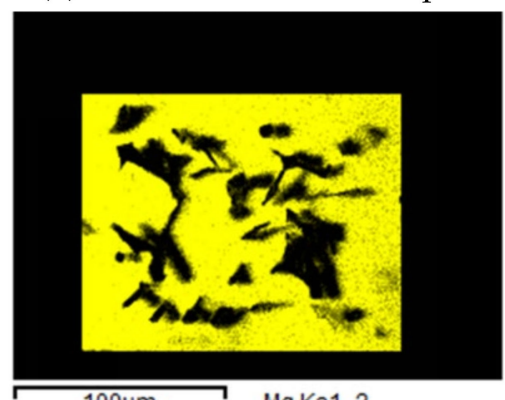

$100 \mu \mathrm{m}$ Mg Ka1_2

(d) distribution of $\mathrm{Mg}$ element

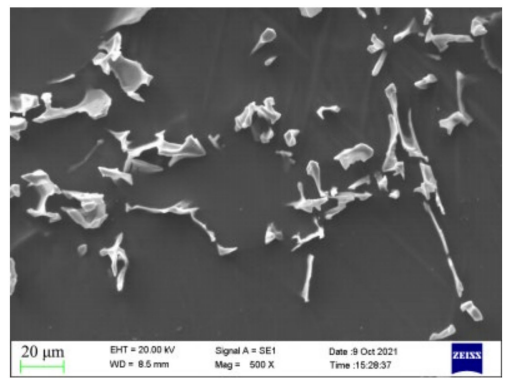

(b) SEM of 3 wt. \% Ce sample

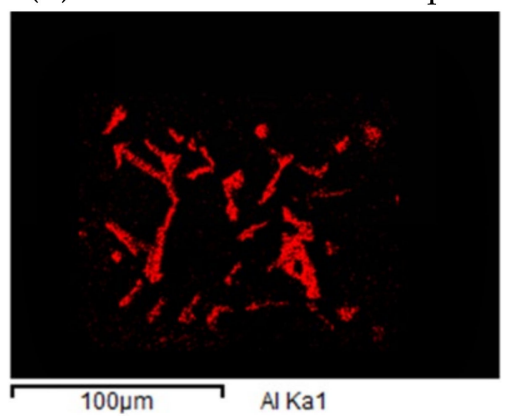

(e) distribution of $\mathrm{Al}$ element

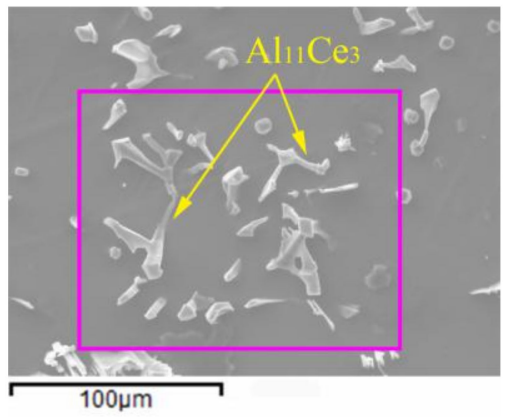

(c) EDS position

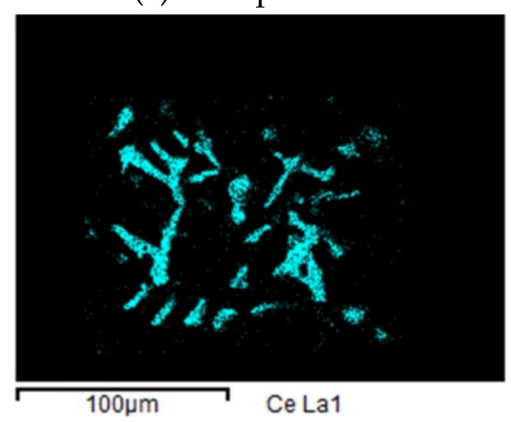

(f) distribution of Ce element

Figure 7. Cont. 


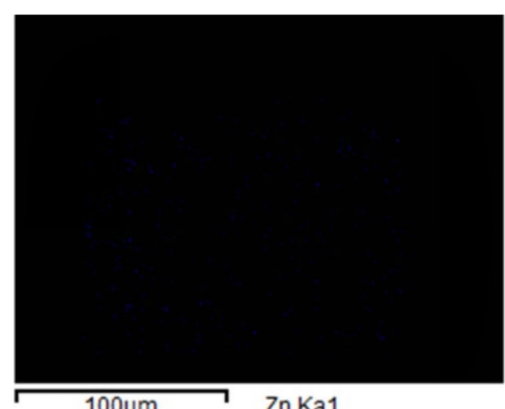

$100 \mu \mathrm{m}$

(g) distribution of $\mathrm{Zn}$ element

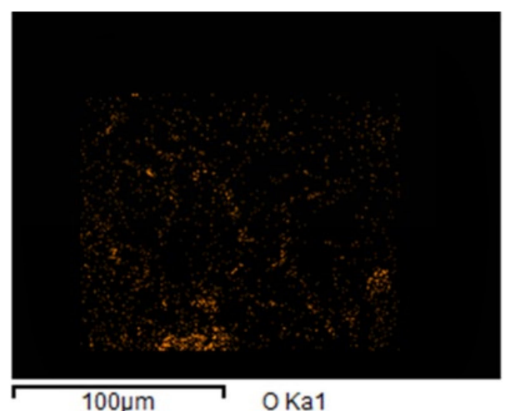

(h) EDS mapping results

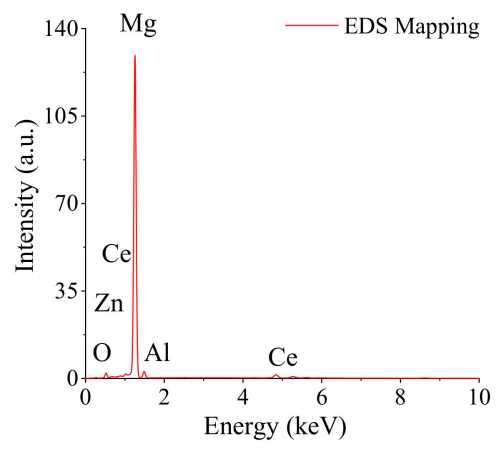

(i) EDS mapping results

Figure 7. Morphology of the sample with 3 wt.\% Ce added.

Notably, the alloying reaction between Ce and the other alloying elements of the matrix reduced the number of nucleation cores, on the one hand, while the quantity of the second phases formed by other alloying elements was sharply decreased, on the other hand (such as $\mathrm{Mg}-\mathrm{Al}, \mathrm{Al}-\mathrm{Zn}, \mathrm{Al}-\mathrm{Mn}$, and $\mathrm{Mg}-\mathrm{Zn}$ phases). However, the intermediate phases precipitated at the grain boundary could hinder the growth of crystal grains effectively, and also hindered the slip of the grain boundary when deformed. Therefore, after adding an excessive amount of $\mathrm{Ce}$, the grain size of the magnesium alloy increased, and the mechanical properties of the alloy could be reduced, as shown in Figure 4d, g,j,m.

\subsection{The Effect of Ce on the Mechanical Properties of Magnesium Alloys}

Tensile samples were sampled from the same position of the ingots with different $\mathrm{Ce}$ contents, and stretched at both ambient temperature and $120^{\circ} \mathrm{C}$; the tensile curves are shown in Figures 8 and 9 . The tensile strength $\left(\sigma_{\mathrm{b}}\right)$ of the as-cast pure magnesium was about $70 \mathrm{MPa}$, with an elongation $(\delta)$ of about $12 \%$ (obtained by the displacement of the chuck) at ambient temperature (Figure 8). As such, the mechanical properties of the pure magnesium were poor, and it would be difficult to meet the requirements of structural materials. However, the $\sigma_{\mathrm{b}}$ was improved to a level of $170 \mathrm{MPa}$ after adding $\mathrm{Al}, \mathrm{Zn}, \mathrm{Mn}$, and other alloying elements to the pure magnesium. However, the changes in $\delta$ were not that obvious, remaining at about $12 \%$. When a further $0.2-0.4 \mathrm{wt} . \% \mathrm{Ce}$ was added to the basis matrix magnesium alloy, the $\sigma_{\mathrm{b}}$ improved slightly to a $180 \mathrm{MPa}$ level, but the $\delta$ increased remarkably to about $50 \%$. Nevertheless, when the added amount of Ce exceeded $0.4 \mathrm{wt} . \%$, the $\sigma_{\mathrm{b}}$ and $\delta$ both tended to decrease, which indicated that an appropriate amount of Ce was critical for the improvement of the plastic product strength.

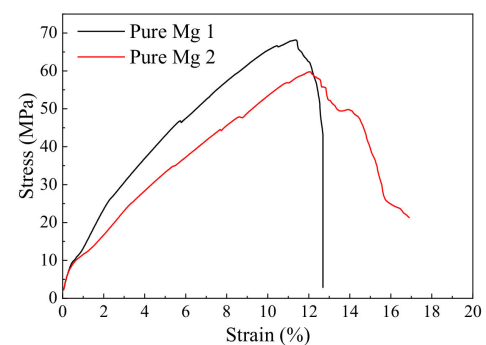

(a) Pure magnesium

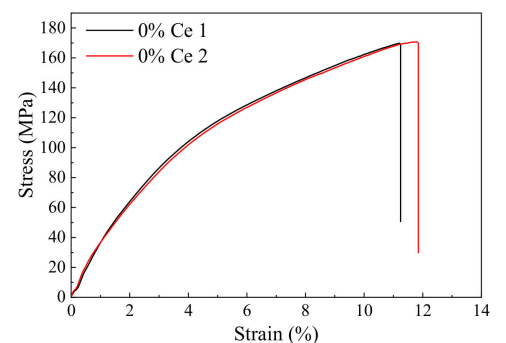

(b) 0 wt. $\% \mathrm{Ce}$

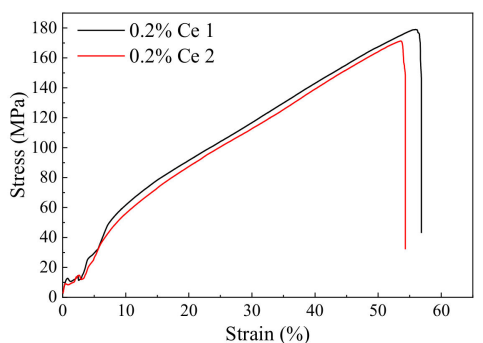

(c) $0.2 \mathrm{wt} . \% \mathrm{Ce}$

Figure 8. Cont. 


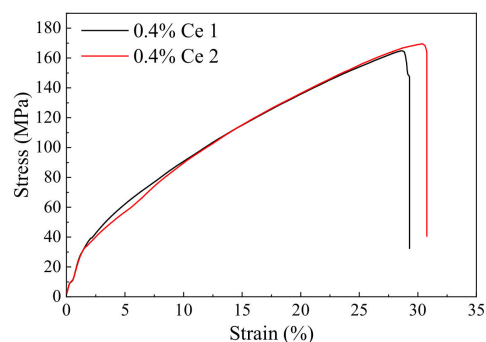

(d) 0.4 wt. $\% \mathrm{Ce}$

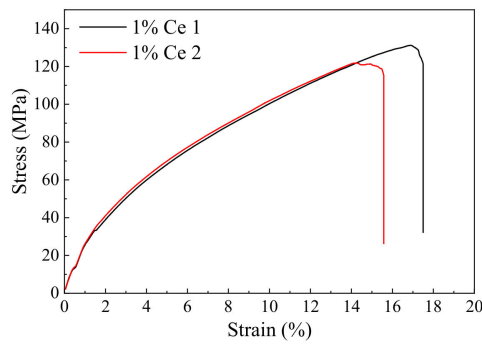

(g) 1 wt.\% Ce

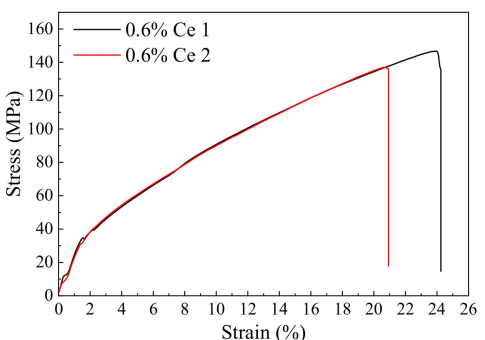

(e) $0.6 \mathrm{wt} \% \mathrm{Ce}$

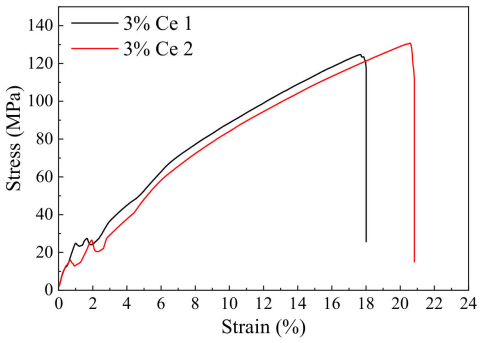

(h) 3 wt. $\% \mathrm{Ce}$

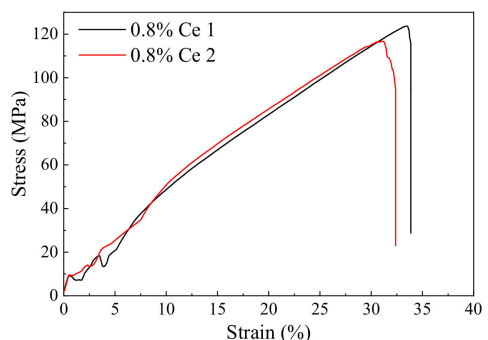

(f) 0.8 wt. $\% \mathrm{Ce}$

Figure 8. Tensile curves of the samples with different Ce contents at ambient temperature.

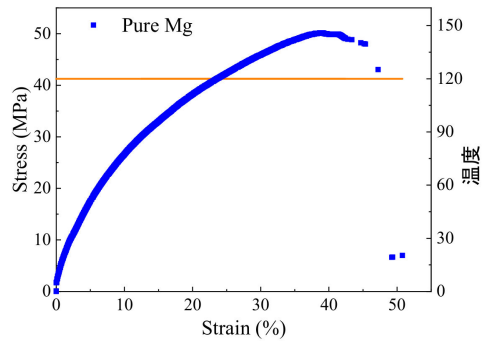

(a) Pure magnesium

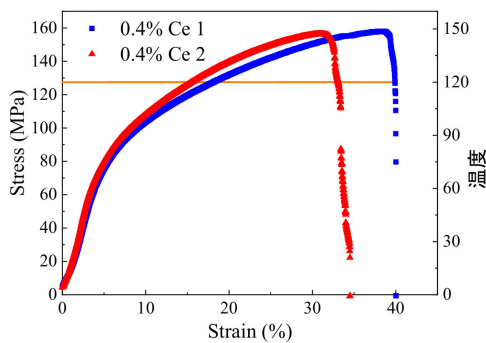

(d) $0.4 \mathrm{wt} . \% \mathrm{Ce}$

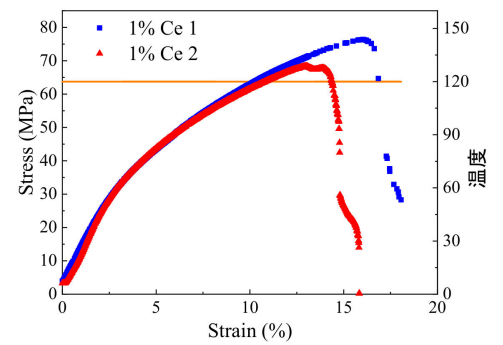

(g) 1 wt.\% Ce

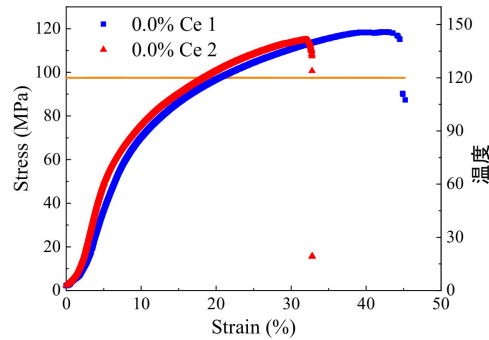

(b) 0 wt. $\% \mathrm{Ce}$

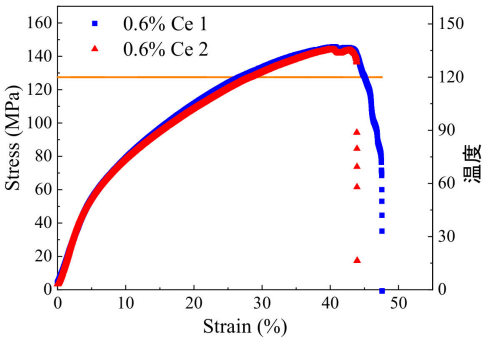

(e) 0.6 wt. $\% \mathrm{Ce}$

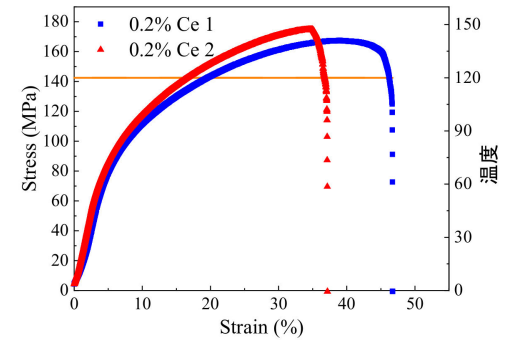

(c) $0.2 \mathrm{wt} . \% \mathrm{Ce}$

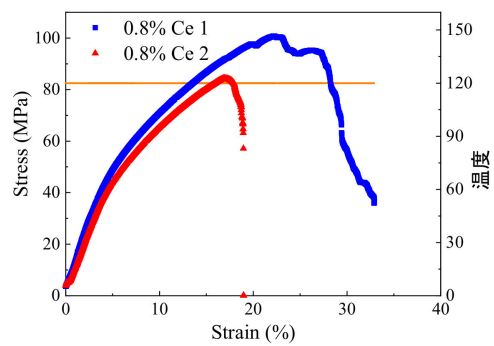

(f) 0.8 wt. $\% \mathrm{Ce}$

Figure 9. The tensile curves of the samples with different Ce content at high temperature. The Chinese on the right sides means Temperature. 
The number of sliding systems of the magnesium alloy at ambient temperature was two, but the prismatic and conical sliding systems were activated at high temperature. As a result, the number of sliding systems was increased to five, which led to poor heat resistance. The tensile curves of the samples with different Ce contents at high temperature are shown in Figure 9, and the comparison data are listed in Table 5. It was obvious that the $\sigma_{b}$ of the pure magnesium and matrix magnesium alloy decreased sharply, with a drop of about $40 \%$ (Figure 9a,b). However, both of them had a significant improvement in elongation, from $12 \%$ to $35 \%$, which indicated the activation of the sliding system. Moreover, the above results meant that conventional elements such as $\mathrm{Al}, \mathrm{Zn}$, and $\mathrm{Mn}$, etc. could not improve the high temperature performance of magnesium alloys. As a comparison, the samples with an appropriate amount of Ce were less sensitive to temperature. The $\sigma_{b}$ of the sample with $0.2 \mathrm{wt} . \% \mathrm{Ce}$ added at $120{ }^{\circ} \mathrm{C}$ was $10 \mathrm{MPa}$ lower compared with that at ambient temperature, and the reduction was lower than $5 \%$, which was maintained at a $170 \mathrm{MPa}$ level (Figure 9c). Moreover, the elongation of the sample varied little and remained at about $40-50 \%$, as at ambient temperature. The sample with $0.4 \mathrm{wt} . \% \mathrm{Ce}$ added showed the same results, with $\mathrm{a} \sigma_{\mathrm{b}}$ at $160 \mathrm{MPa}$ level and a $\delta$ of about $35 \%$ (Figure 9d), which was $170 \mathrm{Mpa}$ and 30\%, respectively, at ambient temperature. The other samples with Ce added exhibited the same improvement in heat resistance. However, with the further increase in the addition of $\mathrm{Ce}$, the tensile strength of the rare earth magnesium alloys at high temperature showed the same decreasing trends as at ambient temperature, which means that the mechanical properties were closely related to the mixed state of the rare earth phase with conventional phases.

Table 5. Comparison of UTS and elongation at ambient temperature and high temperature.

\begin{tabular}{|c|c|c|c|c|c|c|c|c|c|}
\hline \multicolumn{2}{|c|}{ Species } & \multirow{2}{*}{$\begin{array}{c}\text { Pure Mg } \\
68.2\end{array}$} & \multirow{2}{*}{$\begin{array}{c}\text { 0 wt.\% Ce } \\
170.3\end{array}$} & \multirow{2}{*}{$\begin{array}{c}\mathbf{0 . 2} \text { wt. } \% \mathbf{C e} \\
175.2\end{array}$} & \multirow{2}{*}{$\begin{array}{c}\text { 0.4 wt. \% Ce } \\
167.2\end{array}$} & \multirow{2}{*}{$\begin{array}{c}\text { 0.6 wt. \% Ce } \\
141.8\end{array}$} & \multirow{2}{*}{$\begin{array}{c}\mathbf{0 . 8} \text { wt. } \% \text { Ce } \\
120.2\end{array}$} & \multirow{2}{*}{$\begin{array}{c}\text { 1 wt. } \% \text { Ce } \\
122.5\end{array}$} & \multirow{2}{*}{$\begin{array}{c}\text { 3 wt. } \% \text { Ce } \\
123.7\end{array}$} \\
\hline Ambient & $\sigma_{\mathrm{b}}(\mathrm{MPa})$ & & & & & & & & \\
\hline Temp. & $\delta(\%)$ & 11.8 & 11.5 & 54.9 & 29.6 & 22.4 & 32.3 & 16.2 & 19.3 \\
\hline \multirow{2}{*}{$\begin{array}{l}\text { High } \\
\text { Temp. }\end{array}$} & $\sigma_{\mathrm{b}}(\mathrm{MPa})$ & 50.1 & 116.6 & 171.0 & 157.2 & 144.7 & 110.7 & 72.3 & - \\
\hline & $\delta(\%)$ & 38.6 & 39.8 & 41.6 & 36.1 & 44.1 & 23.0 & 15.5 & - \\
\hline
\end{tabular}

Consistent with the tensile tests, the hardness of the alloy was also closely related to the precipitation state of the second phases $[65,66]$. Figure 10 shows the micro hardness curves of the samples with different Ce contents. It can be seen that the hardness of the samples with an appropriate amount of Ce element was much higher than that of the matrix alloy. Among them, the hardness reached a highest value of $55.74 \mathrm{HV}$ when the Ce content was $0.2 \mathrm{wt} . \%$, and where the precipitations were in a state in which a small number of rare earth phases were mixed with the conventional phases. However, as the content of Ce element increased, large numbers of conventional elements, such as Mn, alloyed with Ce and were precipitated [67], which resulted in a sharp decrease in the number of conventional phases. In addition, the hardness of the alloy gradually decreased as a result. When more than $3 \mathrm{wt} . \%$ Ce was added, the hardness of the sample started to become lower than that of the matrix magnesium alloy.

The ambient temperature fracture morphology of matrix magnesium alloy is shown in Figure 11a. A large number of fracture steps and tear ridges appeared in the fracture, which were typical brittle transcrystalline cleavage fractures. For comparison, high temperature fractures of the matrix magnesium alloy are shown in Figure 11b. Obvious small dimples and fracture steps appear at the fracture site, which prove that the high temperature activated the slip system, and that plasticity was exhibited to a certain degree. The fracture mode was a typical quasi-cleavage fracture, which is highly consistent with the hightemperature tensile results. 


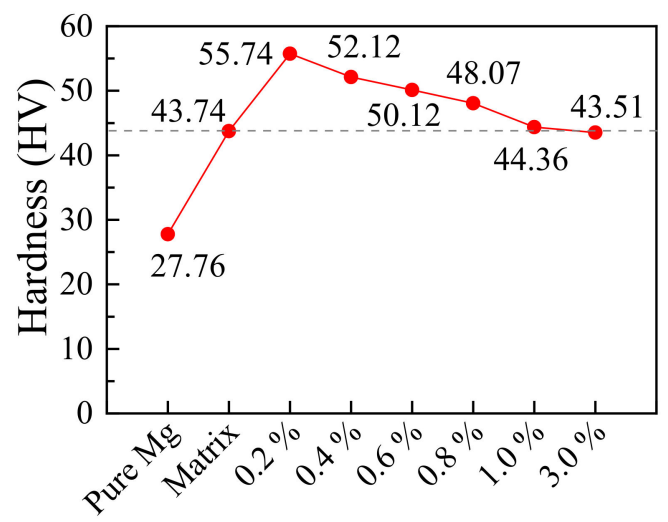

Figure 10. Hardness curve of the samples with different Ce contents.

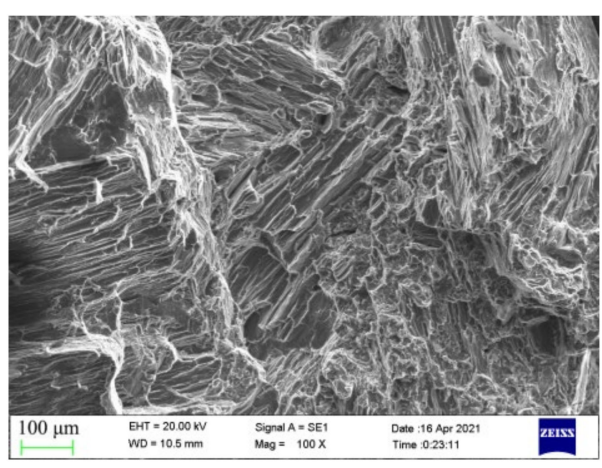

(a) Ambient temperature fracture

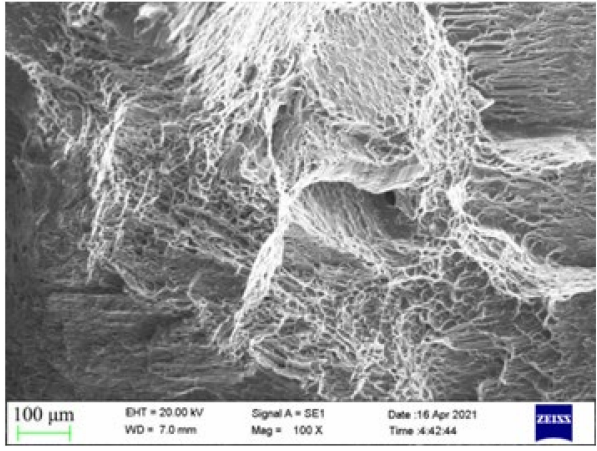

(b) High-temperature fracture

Figure 11. Fracture morphology of matrix magnesium alloy.

The fracture mode of magnesium alloys was not changed with the addition of $\mathrm{Ce}$, as the fracture morphology of the sample with $0.2 \mathrm{wt} . \%$ Ce shows in Figure 12a,b. It was clear that the ambient temperature fractures of the Ce-containing sample had obvious tear ridges and fracture platforms, as in the sample without $\mathrm{Ce}$, and the fracture mode was also brittle cleavage fractures. Tear ridges and a few dimples appeared in the high-temperature fracture, which proved it was a typical quasi-cleavage fracture. Whereas, the size of the dimples was larger than in the samples without $\mathrm{Ce}$, indicating that the sample with $\mathrm{Ce}$ added had a better plasticity.

A magnified observation of the fracture found a needle-like second phase distributed at the bottom of the tear ridge, which was not fused with the matrix metal and penetrated the fracture with a broken shape. The EDS results showed that the phase was mainly composed of $\mathrm{Al}$ and Ce elements, with an atomic ratio of about 3:1 (Figure 12e), which suggests $\mathrm{Al}_{11} \mathrm{Ce}_{3}$ phase. The results above indicated that the high-temperature stable $\mathrm{Al}_{11} \mathrm{Ce}_{3}$ phase could hinder the activation of the $\mathrm{Mg}$ grain slip system during the high temperature deformation process, and the deformation resistance caused the fracture of $\mathrm{Al}_{11} \mathrm{Ce}_{3}$. However, the needle-shaped $\mathrm{Al}_{11} \mathrm{Ce}_{3}$ was prone to stress concentration and cracks, since the $\mathrm{Al}_{11} \mathrm{Ce}_{3}$ phase was not fused with the matrix alloy. Therefore, tensile fractures appeared at the interface of the $\mathrm{Al}_{11} \mathrm{Ce}_{3}$ and the matrix metal, which suggested that more $\mathrm{Al}_{11} \mathrm{Ce}_{3}$ was not always beneficial. 


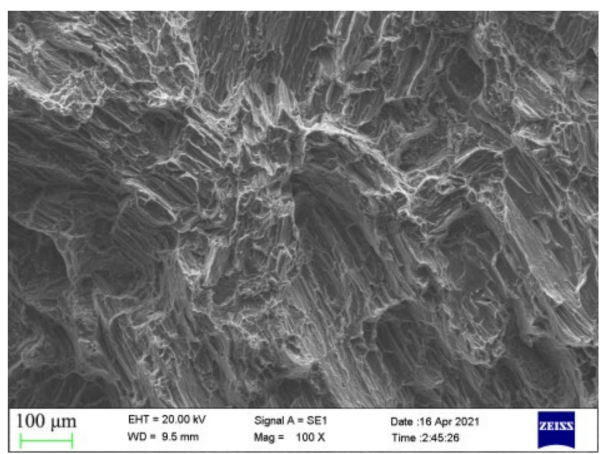

(a) Ambient temperature fracture

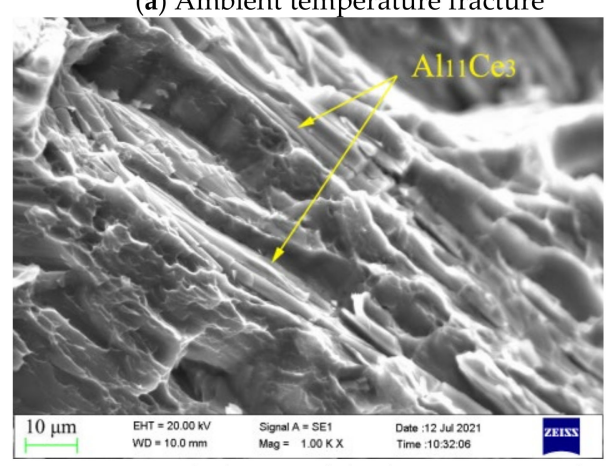

(c) Precipitated phase with high-temperature fracture

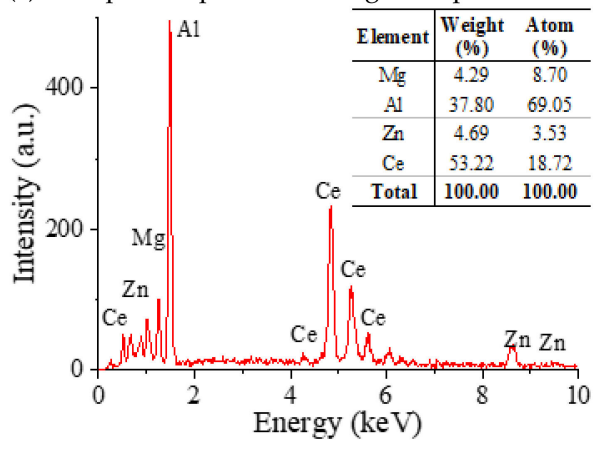

(e) Element compositions of the EDS point

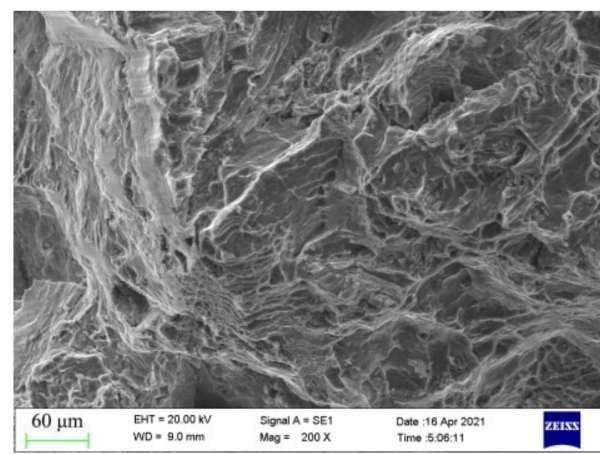

(b) High-temperature fracture
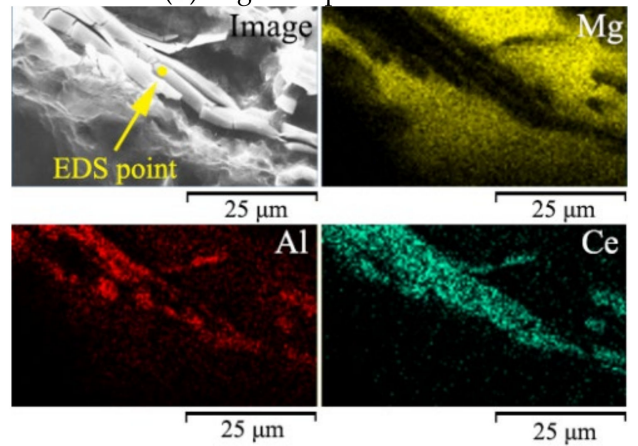

(d) EDS mapping results of the precipitated phase

Figure 12. Fracture morphology of the sample with 0.2 wt.\% Ce.

\subsection{The Strengthening Mechanism of Ce in the Magnesium Alloy of Mg-Al Series}

According to electronegativity theory [64], in the Mg-Al-Zn-Mn-Ce multi-elements alloying system in this work, the electronegativity difference between Ce with $\mathrm{Mn}, \mathrm{Al}$, $\mathrm{Zn}$, and $\mathrm{Mg}$ decreased gradually. Therefore, the Ce preferentially alloyed with Mn to form $\mathrm{Al}_{10} \mathrm{Ce}_{2} \mathrm{Mn}_{7}$ phase. Owing to the low content of $\mathrm{Mn}$ in the matrix magnesium alloy, the excess $\mathrm{Ce}$ then alloyed with $\mathrm{Al}, \mathrm{Zn}, \mathrm{Mg}$, and other elements sequentially to form the corresponding Al-Ce, $\mathrm{Zn}-\mathrm{Ce}$, and $\mathrm{Mg}$-Ce phases, until the Ce was exhausted. However, the $\mathrm{Al}$ added to the matrix magnesium alloys was generally sufficient to completely consume all of the Ce element, and $\mathrm{Al}_{11} \mathrm{Ce}_{3}$ was formed as a result. Therefore, it was difficult to find $\mathrm{Zn}-\mathrm{Ce}$ and $\mathrm{Mg}-\mathrm{Ce}$ phases in the alloy, while the remaining $\mathrm{Al}$ alloyed with $\mathrm{Mg}$ to form $\mathrm{Mg}_{17} \mathrm{Al}_{12}$. This derivation is consistent with the component analysis results obtained previously in this study.

By using an edge-edge matching model [68], a set of crystal orientation relationship data was obtained by calculating the crystal plane spacing mismatch between the closepacked surfaces of $\alpha-\mathrm{Mg}$ with $\mathrm{Al}_{10} \mathrm{Ce}_{2} \mathrm{Mn}_{7}$ and $\mathrm{Al}_{11} \mathrm{Ce}_{3}$ phases. Therefore, whether the preferentially precipitated $\mathrm{Al}_{10} \mathrm{Ce}_{2} \mathrm{Mn}_{7}$ and $\mathrm{Al}_{11} \mathrm{Ce}_{3}$ served as the nucleation core of $\alpha-\mathrm{Mg}$ was investigated. Taking $\mathrm{Al}_{11} \mathrm{Ce}_{3}$ as an example, the three close-packed surfaces of $\alpha-\mathrm{Mg}$ were $\{0002\},\{1011\}$, and $\{1010\}$, and the three close-packed surfaces of $\mathrm{Al}_{11} \mathrm{Ce}_{3}$ were $\{011\}$, 
$\{002\}$, and $\{101\}$, respectively. According to the mismatch in Equation (3), the calculated crystal surfaces mismatch $\left(\mathrm{f}_{\mathrm{d}}\right)$ between $\alpha-\mathrm{Mg}$ and $\mathrm{Al}_{11} \mathrm{Ce}_{3}$ is shown in Table 6.

$$
f_{d}=\left|\frac{d_{M g}-d_{A l_{11} C_{3}}}{d_{M g}}\right| \times 100 \%
$$

Table 6. The crystal surfaces mismatch between $\alpha-\mathrm{Mg}$ and $\mathrm{Al}_{11} \mathrm{Ce}_{3}$.

\begin{tabular}{lccccc}
\hline & $\boldsymbol{F}_{\boldsymbol{d}}(\mathbf{\%})$ & & \multicolumn{3}{c}{$\boldsymbol{d}_{\boldsymbol{M g}}$} \\
\cline { 3 - 5 } & & $\mathbf{2 . 6 0 5 0}$ & $\mathbf{2 . 4 5 2 0}$ & $\mathbf{2 . 7 7 8 2}$ \\
\hline \multirow{3}{*}{$\boldsymbol{d}_{\boldsymbol{A} l_{11} C e_{3}}$} & 7.9776 & 206.24 & 225.35 & 187.15 \\
\cline { 2 - 5 } & 5.0460 & 93.70 & 105.79 & 81.63 \\
\cline { 2 - 5 } & 4.0295 & 54.68 & 64.34 & 45.04 \\
\hline
\end{tabular}

The mismatch between $\alpha-\mathrm{Mg}$ and $\mathrm{Al}_{10} \mathrm{Ce}_{2} \mathrm{Mn}_{7}$ was calculated using the same method. The mismatches of $\alpha-\mathrm{Mg}$ with $\mathrm{Al}_{11} \mathrm{Ce}_{3}$ and $\mathrm{Al}_{10} \mathrm{Ce}_{2} \mathrm{Mn}_{7}$ were much greater than $25 \%$, which meant that they could not act as the nucleation core for $\alpha-\mathrm{Mg}$. The grain refinement mechanism after the addition of Ce element was primarily that the precipitated phases distributed along the grain boundaries hindered the growth of the grains. Therefore, the effect of $\mathrm{Ce}$ on the grain refinement of magnesium alloys was not satisfactory. On the country, after adding an excessive amount of Ce element, the number of other intermediate phases and particles that should have been precipitated in the matrix magnesium alloy was sharply reduced, due to the preferential alloying of Ce with $\mathrm{Mn}, \mathrm{Al}, \mathrm{Zn}$, etc., and these phases could act as nucleation cores or hinder the growth of grains at the grain boundary. Therefore, the grain size increased instead. This was verified by the microstructure morphology in Figure 4 and discussed in Section 4.1.

Based on the above theoretical analysis results, and combined with the Al-Ce and $\mathrm{Mg}-\mathrm{Al}$ binary phase diagrams, and Al-Mn-Ce ternary phase diagrams, the strengthening mechanism of Ce element in the solidification process of $\mathrm{Mg}$-Al alloys was deduced, which was divided into three stages, according to the temperature range, as shown in Figure 13.

(1) Between $750{ }^{\circ} \mathrm{C}$ and $641{ }^{\circ} \mathrm{C}$ : According to the research results of Qiang Yang [55], $\mathrm{Al}_{10} \mathrm{Ce}_{2} \mathrm{Mn}_{7}$ was transformed from $\mathrm{Al}_{8} \mathrm{CeMn}_{4}$. Gil Coury [53] confirmed that the two $\mathrm{Al}$ atoms in $\mathrm{Al}_{10} \mathrm{CeMn}_{2}$ were replaced by $\mathrm{Mn}$ atoms and converted into $\mathrm{Al}_{8} \mathrm{CeMn}_{4}$, which were observed using the TEM method, with both of them having similar properties and the melting point of $\mathrm{Al}_{8} \mathrm{CeMn}_{4}$ being $1191^{\circ} \mathrm{C}$. F. G. Coury [69] found that $\mathrm{Al}_{8} \mathrm{CeMn}_{4}$ was more likely to form at the Al-rich corner in Al-Mn-Ce ternary alloys, which was similar to the situation in this paper. The phase diagram calculations of $\mathrm{Y}$. Yang [70] showed that $\mathrm{Al}_{10} \mathrm{CeMn}_{2}$ was transformed at $738^{\circ} \mathrm{C}$ and $700^{\circ} \mathrm{C}$. Therefore, it could be inferred that the formation temperature of $\mathrm{Al}_{8} \mathrm{CeMn}_{4}$ (which could be converted into $\mathrm{Al}_{10} \mathrm{Ce}_{2} \mathrm{Mn}_{7}$ ) was also around $700{ }^{\circ} \mathrm{C}$. Combined with electronegativity theory, it was suggested that the $\mathrm{Al}_{10} \mathrm{Ce}_{2} \mathrm{Mn}_{7}$ phase was preferentially formed from $\mathrm{Al}, \mathrm{Ce}$, and $\mathrm{Mn}$ elements, and solidified and dispersed at about $700{ }^{\circ} \mathrm{C}$, when the matrix magnesium alloy was still in a liquid state. However, more specific formation temperatures and forming theories have rarely been reported $[38,41]$, and need further study.

(2) Between $641^{\circ} \mathrm{C}$ and $436{ }^{\circ} \mathrm{C}$ : The liquidus of magnesium alloy was about $650{ }^{\circ} \mathrm{C}$, and the $\mathrm{Al}_{11} \mathrm{Ce}_{3}$ was precipitated through a eutectic reaction $\mathrm{Liq} \leftrightarrow \mathrm{Al}_{11} \mathrm{Ce}_{3}+\alpha-\mathrm{Al}$ at $641{ }^{\circ} \mathrm{C}$ [42]. However, the preferentially precipitated $\mathrm{Al}_{10} \mathrm{Ce}_{2} \mathrm{Mn}_{7}$ and $\mathrm{Al}_{11} \mathrm{Ce}_{3}$ phases could not act as the nucleation particles of $\alpha-\mathrm{Mg}$, according to the mismatch calculations results. Therefore, the precipitated $\mathrm{Al}_{11} \mathrm{Ce}_{3}$ and $\mathrm{Al}_{10} \mathrm{Ce}_{2} \mathrm{Mn}_{7}$ phases adhered to the $\alpha-\mathrm{Mg}$ surface and were distributed along the grain boundary, which inhibited the growth of the primary $\alpha$-Mg grains, thus achieving the effect of grain refinement. Whereas, the Ce content was less than $1 \mathrm{wt} . \%$, the $\mathrm{Al}$ element in the 
matrix alloy was sufficient to fully alloy with $\mathrm{Ce}$, and the residual $\mathrm{Al}$ then further alloyed with $\mathrm{Mg}$, following the order in electronegativity theory.

(3) Between $436{ }^{\circ} \mathrm{C}$ and ambient temperature: the typical $\mathrm{Mg}_{17} \mathrm{Al}_{12}$ was generated at $436{ }^{\circ} \mathrm{C}$ through an eutectic reaction $\mathrm{Liq} \leftrightarrow \mathrm{Mg}_{17} \mathrm{Al}_{12}+\alpha-\mathrm{Mg}$ [47]. Since $\mathrm{Al}_{10} \mathrm{Ce}_{2} \mathrm{Mn}_{7}$ and $\mathrm{Al}_{11} \mathrm{Ce}_{3}$ had already been distributed along the grain boundary at this temperature, this blocked the $\mathrm{Mg}_{17} \mathrm{Al}_{12}$ from forming a network/continuous morphology. Therefore, the precipitated $\mathrm{Mg}_{17} \mathrm{Al}_{12}$ phase after the addition of Ce was mainly in the shape of islands or clumps at the grain boundary, and a mixed strengthening structure of rare earth phase and conventional phase was formed. As a matter of fact, the melting point of $\mathrm{Mg}_{17} \mathrm{Al}_{12}$ was only $467^{\circ} \mathrm{C}$, whereas the melting point of $\mathrm{Al}_{10} \mathrm{Ce}_{2} \mathrm{Mn}_{7}$ and $\mathrm{Al}_{11} \mathrm{Ce}_{3}$ was above $1000{ }^{\circ} \mathrm{C}[43,50,55]$. In addition, the Ce-containing rare earth phase was not solid soluble in magnesium, and the heat resistance and high temperature strength of the magnesium alloy were significantly improved by adding an appropriate amount of $\mathrm{Ce}$. However, with the increased addition of $\mathrm{Ce}, \mathrm{a}$ large amount of conventional alloying elements $(\mathrm{Mn}, \mathrm{Al}, \mathrm{Zn}$, etc.) were consumed. As a result, the strengthening phases in the magnesium alloy gradually changed from a mixed strengthening structure of rare earth and conventional precipitated phases to a single rare earth phase structure. However, the acicular $\mathrm{Al}_{11} \mathrm{Ce}_{3}$ phase was not fused with the magnesium matrix, which generated stress and formed microcracks. Therefore, excessive Ce element addition reduces the mechanical properties of an alloy.

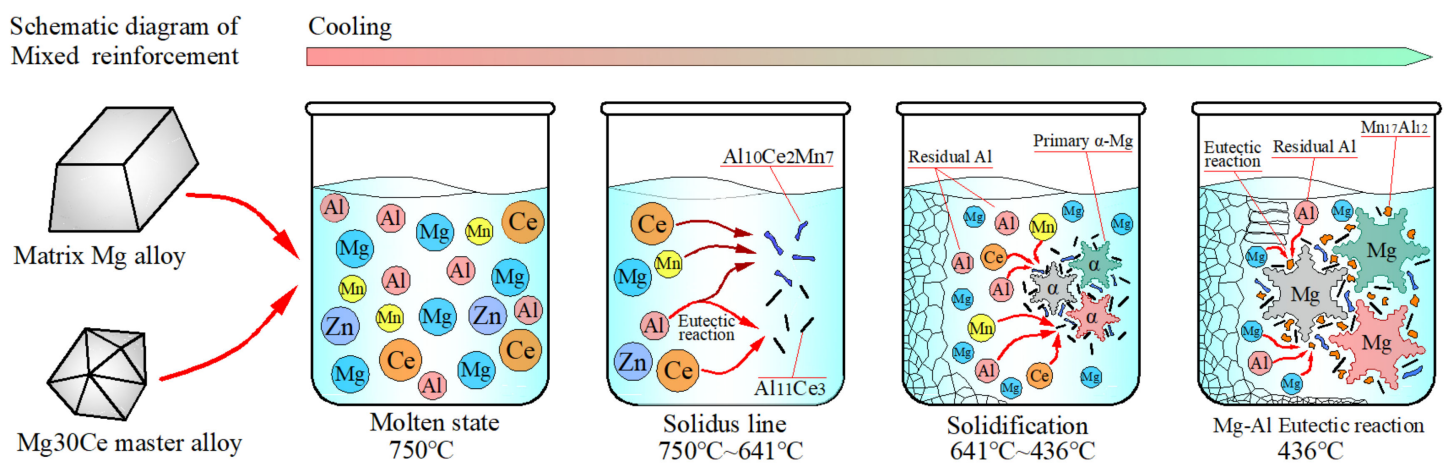

Figure 13. The strengthening mechanism of Ce element in the solidification process of $\mathrm{Mg}$-Al alloys.

In conclusion, the best way to improve the mechanical properties of Ce rare earth magnesium alloys is to adjust the proportion of Ce element added, so as to form a mixed strengthening structure of rare earth phase with conventional strengthening phase, which is of great significance for the design of magnesium alloys.

\section{Conclusions}

(1) The first-principle calculation results showed that the formation enthalpy and cohesive energy of the Al-Ce series phase were much higher than that of the $\mathrm{Mg}-\mathrm{Al}$ and $\mathrm{Mg}$-Ce series phases in a Mg-Al-Ce ternary alloy system, which meant that Ce would preferentially alloy with $\mathrm{Al}$ element to form $\mathrm{Al}-\mathrm{Ce}$ phase. While $\mathrm{Mg}-\mathrm{Al}$ phase and $\mathrm{Mg}$-Ce phase would be formed in sequence when the Ce was completely consumed. The calculation results were highly consistent with electronegativity theory.

(2) The microstructure and composition analyses of the alloy found that the strengthening phase of magnesium alloy after adding Ce element was mainly needle-like $\mathrm{Al}_{11} \mathrm{Ce}_{3}$; rod-like $\mathrm{Al}_{10} \mathrm{Ce}_{2} \mathrm{Mn}_{7}$, which was distributed at the grain boundary and through the grains; and $\mathrm{Mg}_{17} \mathrm{Al}_{12}$ phase, which was broken into granular or island shapes at the grain boundary. In combination with mismatch theory, it was proven that the preferentially precipitated $\mathrm{Al}_{11} \mathrm{Ce}_{3}$ and $\mathrm{Al}_{10} \mathrm{Ce}_{2} \mathrm{Mn}_{7}$ phases could not act as the nucleation core of $\alpha-\mathrm{Mg}$, but instead were precipitated at the grain boundary, thereby 
blocking the continuous distribution of $\mathrm{Mg}_{17} \mathrm{Al}_{12}$. While, a reinforced structure was formed, with the rare earth phase mixed with conventional phase.

(3) The tensile results at ambient temperature and high temperature showed that a strengthened structure of rare earth phase mixed with conventional strengthening phase was beneficial for improving the comprehensive mechanical properties of magnesium alloys, by adding an appropriate amount of Ce element; with the appropriate Ce addition range being 0.2-0.4 wt \%. After adding an excessive amount of Ce element, the strengthening phase of the alloy was mainly $\mathrm{Al}_{11} \mathrm{Ce}_{3}$. While, the acicular $\mathrm{Al}_{11} \mathrm{Ce}_{3}$, which did not fuse with the matrix, easily became the source of cracking, due to the stress concentration, and reduced the mechanical properties of the alloy.

(4) Combined with electronegativity theory, the mechanism of the microstructural evolution of a Mg-Al-Zn-Ce-Mn multi-elements alloy during solidification was simplified, with temperature as the dimension, and the strengthening mechanism of Ce element in magnesium alloys was deduced.

Author Contributions: Conceptualization, Y.C. and Z.Z.; methodology, Z.Z. and J.Z.; Software, Y.C.; Validation, Z.Z., J.Z. and H.L.; Formal analysis, Y.C. and Z.Z.; Investigation, Y.C.; Resources, Y.C. and Z.Z.; Data curation, Y.C.; Writing—original draft preparation, Y.C.; Writing—-review and editing, Z.Z. and J.Z.; Visualization, Z.Z.; Supervision, J.Z.; Project administration, Y.C.; Funding acquisition, Y.C. All authors have read and agreed to the published version of the manuscript.

Funding: This research was funded by (1) the Natural Science Foundation of Jiangxi ProvinceGeneral Project (No. 20202BABA204009); (2) the Key Research and Development Program of Jiangxi Province (No. 20203BBG73070).

Institutional Review Board Statement: Not applicable.

Informed Consent Statement: Not applicable.

Data Availability Statement: Not applicable.

Acknowledgments: The work in this paper was supported by (1) the Natural Science Foundation of Jiangxi Province-General Project (No. 20202BABA204009); (2) the Key Research and Development Program of Jiangxi Province (No. 20203BBG73070).

Conflicts of Interest: The authors declare no conflict of interest.

\section{References}

1. Fu, S.; Li, Q.; Jing, X.; Zhang, Q.; Chen, Z.; Liu, W. Review on Research and Development of Heat Resistant Magnesium Alloy; Atlantis Press: Paris, France, 2012; pp. 682-685.

2. Jiao, F.W.; Jin, L.; Dong, J.; Wang, F.H. In situ electron backscatter diffraction analysis for microstructure evolution and deformation models of Mg-Ce alloy during uniaxial loading. Acta Metall. Sin. (Engl. Lett.) 2019, 32, 263-268. [CrossRef]

3. Zhang, C.; Han, P.; Yan, X.; Wang, C.; Xia, L.; Xu, B. First-principles study of typical precipitates in creep resistant magnesium alloys. J. Phys. D Appl. Phys. 2009, 42, 125403. [CrossRef]

4. Pekguleryuz, M.; Celikin, M. Creep resistance in magnesium alloys. Int. Mater. Rev. 2010, 55, 197-217. [CrossRef]

5. Mordike, B.L.; Ebert, T. Magnesium: Properties-applications-potential. Mater. Sci. Eng. A 2001, 302, 37-45. [CrossRef]

6. Pekguleryuz, M.O.; Kaya, A.A. Creep resistant magnesium alloys for powertrain applications. Adv. Eng. Mater. 2003, 5, 866-878.

7. Wu, G.; Wang, C.; Sun, M.; Ding, W. Recent developments and applications on high-performance cast magnesium rare-earth alloys. J. Magnes. Alloys. 2020, 9, 1-20.

8. Zhang, J.; Liu, S.; Wu, R.; Hou, L.; Zhang, M. Recent developments in high-strength Mg-RE-based alloys: Focusing on Mg-Gd and Mg-Y systems. J. Magnes. Alloys. 2018, 6, 277-291. [CrossRef]

9. Luo, Q.; Guo, Y.; Liu, B.; Feng, Y.; Zhang, J.; Li, Q.; Chou, K. Thermodynamics and kinetics of phase transformation in rare earth-magnesium alloys: A critical review. J. Mater. Sci. Technol. 2020, 44, 171-190.

10. Wang, B.; Liu, C.; Gao, Y.; Jiang, S.; Chen, Z.; Luo, Z. Microstructure evolution and mechanical properties of Mg-Gd-Y-Ag-Zr alloy fabricated by multidirectional forging and ageing treatment. Mater. Sci. Eng. A 2017, 702, 22-28. [CrossRef]

11. Ding, Z.B.; Zhao, Y.H.; Lu, R.P.; Yuan, M.N.; Wang, Z.J.; Li, H.J.; Hua, H.O. Effect of Zn addition on microstructure and mechanical properties of cast Mg-Gd-Y-Zr alloys. Trans. Nonferrous Met. Soc. China 2019, 29, 722-734. [CrossRef]

12. Wang, Y.; Zhang, F; Wang, Y.; Duan, Y.; Wang, K.; Zhang, W.; Hu, J. Effect of Zn content on the microstructure and mechanical properties of Mg-Gd-Y-Zr alloys. Mater. Sci. Eng. A 2019, 745, 149-158. [CrossRef]

13. Lyu, S.; Xiao, W.; Li, G.; Zheng, R.; Ma, C. Achieving enhanced mechanical properties in Mg-Y-Sm-Zr alloy by altering precipitation behaviors through Zn addition. Mater. Sci. Eng. A 2019, 746, 179-186. [CrossRef] 
14. Liu, N.; Zhang, Z.; Peng, L.; Ding, W. Microstructure evolution and mechanical properties of Mg-Gd-Sm-Zr alloys. Mater. Sci. Eng. A 2015, 627, 223-229. [CrossRef]

15. Zheng, K.Y.; Dong, J.; Zeng, X.Q.; Ding, W.J. Precipitation and its effect on the mechanical properties of a cast Mg-Gd-Nd-Zr alloy. Mater. Sci. Eng. A 2008, 489, 44-54. [CrossRef]

16. Liu, X.B.; Chen, R.S.; Han, E.H. Effects of ageing treatment on microstructures and properties of Mg-Gd-Y-Zr alloys with and without Zn additions. J. Alloys Compd. 2008, 465, 232-238. [CrossRef]

17. Li, D.J.; Zeng, X.Q.; Jie, D.O.; Zhai, C.Q. Influence of heat treatment on microstructure and mechanical properties of Mg-10Gd-3Y1.2 Zn-0.4Zr alloy. Trans. Nonferrous Met. Soc. China 2008, 18, s117-s121.

18. Li, J.; He, Z.; Fu, P.; Wu, Y.; Peng, L.; Ding, W. Heat treatment and mechanical properties of a high-strength cast Mg-Gd-Zn alloy. Mater. Sci. Eng. A 2016, 651, 745-752. [CrossRef]

19. Yamada, K.; Hoshikawa, H.; Maki, S.; Ozaki, T.; Kuroki, Y.; Kamado, S.; Kojima, Y. Enhanced age-hardening and formation of plate precipitates in Mg-Gd-Ag alloys. Scr. Mater. 2009, 61, 636-639. [CrossRef]

20. Zhang, Y.; Rong, W.; Wu, Y.; Peng, L.; Nie, J.-F.; Birbilis, N. A comparative study of the role of Ag in microstructures and mechanical properties of Mg-Gd and Mg-Y alloys. Mater. Sci. Eng. A 2018, 731, 609-622. [CrossRef]

21. Gao, X.; Nie, J.F. Enhanced precipitation-hardening in Mg-Gd alloys containing Ag and Zn. Scr. Mater. 2008, 58, 619-622. [CrossRef]

22. Nie, J.F. Precipitation and hardening in magnesium alloys. Mater. Sci. Eng. A 2012, 43, 3891-3939.

23. Liu, W.; Zhou, B.; Wu, G.; Zhang, L.; Peng, X.; Cao, L. High temperature mechanical behavior of low-pressure sand-cast Mg-Gd-Y-Zr magnesium alloy. J. Magnes. Alloys 2019, 7, 597-604. [CrossRef]

24. Imandoust, A.; Barrett, C.D.; Oppedal, A.L.; Whittington, W.R.; Paudel, Y.; El Kadiri, H. Nucleation and preferential growth mechanism of recrystallization texture in high purity binary magnesium-rare earth alloys. Acta Mater. 2017, 138, 27-41. [CrossRef]

25. Yan, Z.; Fang, M.; Lian, Z.; Zhang, Z.; Zhu, J.; Zhang, G.; Wang, Y. Research on AZ80 + 0.4\% Ce (wt\%) ultra-thin-walled tubes of magnesium alloys: The forming process, microstructure evolution and mechanical properties. Metals 2019, 9, 563. [CrossRef]

26. Kondori, B.; Mahmudi, R. Effect of Ca additions on the microstructure, thermal stability and mechanical properties of a cast AM60 magnesium alloy. Mater. Sci. Eng. A 2010, 527, 2014-2021. [CrossRef]

27. Hirai, K.; Somekawa, H.; Takigawa, Y.; Higashi, K. Effects of Ca and Sr addition on mechanical properties of a cast AZ91 magnesium alloy at room and elevated temperature. Mater. Sci. Eng. A 2005, 403, 276-280. [CrossRef]

28. Wang, M.; Xiao, D.H.; Liu, W.S. Effect of Si addition on microstructure and properties of magnesium alloys with high $\mathrm{Al}$ and $\mathrm{Zn}$ contents. Vacuum 2017, 141, 144-151. [CrossRef]

29. Marjani, O.; Emamy, M.; Mirzadeh, H. Mechanical behavior of as-cast and extruded Mg-Si-Ni-Ca magnesium alloys. J. Mater. Eng. Perform. 2020, 29, 7728-7735. [CrossRef]

30. Jing, B.; Sun, Y.; Xun, S.; Xue, F.; Zhu, T. Microstructure and tensile creep behavior of Mg-4Al based magnesium alloys with alkaline-earth elements Sr and Ca additions. Mater. Sci. Eng. A 2006, 419, 181-188.

31. Afsharnaderi, A.; Lotfpour, M.; Mirzadeh, H.; Emamy, M.; Malekan, M. Enhanced mechanical properties of as-cast AZ91 magnesium alloy by combined RE-Sr addition and hot extrusion. Mater. Sci. Eng. A 2020, 792, 139817. [CrossRef]

32. Zhang, X.M.; Peng, Z.K.; Chen, J.M.; Deng, Y.L. Heat-resistant magnesium alloys and their development. Trans. Nonferrous Met. Soc. China 2004, 14, 1443-1450.

33. Mordike, B.L. Creep-resistant magnesium alloys. Mater. Sci. Eng. A 2002, 324, 103-112. [CrossRef]

34. Paulick, H.; Machacek, E. The global rare earth element exploration boom: An analysis of resources outside of China and discussion of development perspectives. Resour. Policy 2017, 52, 134-153. [CrossRef]

35. Zhang, X.; Kevorkov, D.; Pekguleryuz, M.O. Study on the binary intermetallic compounds in the Mg-Ce system. Intermetallics 2009, 17, 496-503.

36. Imandoust, A.; Barreett, C.; Al-Samman, T.; Tschopp, M.A.; Essadiqi, E.; Hort, N.; El Kadiri, H. Unraveling recrystallization mechanisms governing texture development from rare-earth element additions to magnesium. Mater. Sci. Eng. A 2018, 49, 1809-1829.

37. Zhang, X.; Kevorkov, D.; Pekguleryuz, M.O. Study on the intermetallic phases in the Mg-Ce system: Part II. Diffusion couple investigation. J. Alloys Compd. 2010, 501, 366-370. [CrossRef]

38. Kang, Y.B.; Pelton, A.D.; Chartrand, P.; Spencer, P.; Fuerst, C.D. Critical Evaluation and Thermodynamic Optimization of the Binary Systems in the Mg-Ce-Mn-Y System. J. Phase Equilib. Diffus. 2007, 28, 342-354. [CrossRef]

39. Shi, H.; Li, Q.; Zhang, J.; Luo, Q.; Chou, K.C. Re-assessment of the Mg-Zn-Ce system focusing on the phase equilibria in Mg-rich corner. Calphad 2020, 68, 101742 .

40. Renju, C.H.; Hanwu, D.O.; Wenjun, L.I.; Bin, J.I.; Shutao, X.I.; Bo, L.I.; Fusheng, P.A. Effect of Al-and Ce-content on Microstructure of Mg-Al Magnesium Alloys. Chin. J. Mater. Res. 2017, 31, 737-742.

41. Zhu, M.; Jian, Z.Y.; Yao, L.J.; Liu, C.; Yang, G.; Zhou, Y. Effect of mischmetal modification treatment on the microstructure, tensile properties, and fracture behavior of Al-7.0\%Si-0.3\%Mg foundry aluminum alloys. J. Mater. Sci. 2010, 46, 2685-2694. [CrossRef]

42. Wu, R.Z.; Qu, Z.K.; Zhang, M.L. Reviews on the influences of alloying elements on the microstructure and mechanical properties of Mg-Li base alloys. Rev. Adv. Mater. Sci. 2010, 24, 35-43.

43. Zhang, M.J.; Yang, X.H.; Liu, Y.B.; Cao, Z.Y.; Cheng, L.R.; Pei, Y.L. Effect of graphite content on wear property of graphite $/ \mathrm{Al}_{2} \mathrm{O}_{3} / \mathrm{Mg}-9 \mathrm{Al}-1 \mathrm{Zn}-0.8 \mathrm{Ce}$ composites. Trans. Nonferrous Met. Soc. China 2010, 20, 207-211. 
44. Mert, F.; Özdemir, A.; Kainer, K.U.; Hort, N. Influence of Ce addition on microstructure and mechanical properties of high pressure die cast AM 50 magnesium alloy. Trans. Nonferrous Met. Soc. China 2013, 23, 66-72. [CrossRef]

45. Wang, W.Y.; Li, J.; Liu, W.; Liu, Z.K. Integrated computational materials engineering for advanced materials: A brief review. Comput. Mater. Sci. 2019, 158, 42-48. [CrossRef]

46. Zhang, H. Thermodynamic Properties of mg Based Alloys by Calphad Approach Coupled with First-Principles: Application to mg-al-ca-ce-si System. Ph.D. Thesis, The Pennsylvania State University, Philadelphia, PA, USA, 2010.

47. Zhou, Y.; Dang, M.; Sun, L.; Zhai, W.; Dong, H.; Gao, Q.; Zhao, F.; Peng, J. First-principle studies on the electronic structural, thermodynamics and elastic properties of $\mathrm{Mg}_{17} \mathrm{Al}_{12}$ intermediate phase under high pressure. Mater. Res. Express 2019, 6, 0865e1. [CrossRef]

48. Huang, Z.W.; Zhao, Y.H.; Hou, H.; Han, P.D. Electronic structural, elastic properties and thermodynamics of $\mathrm{Mg}_{17} \mathrm{Al}_{12}, \mathrm{Mg}_{2} \mathrm{Si}$ and $\mathrm{Al}_{2} \mathrm{Y}$ phases from first-principles calculations. Phys. B 2012, 407, 1075-1081. [CrossRef]

49. Zheng, B.; Zhao, L.; Hu, X.; Dong, S.; Li, H. First-principles studies of $\mathrm{Mg}_{17} \mathrm{Al}_{12}, \mathrm{Mg}_{2} \mathrm{Al}_{3}, \mathrm{Mg}_{2} \mathrm{Sn}_{1} \mathrm{MgZn}_{2}, \mathrm{Mg}_{2} \mathrm{Ni}$ and $\mathrm{Al}_{3} \mathrm{Ni}$ phases. Phys. B 2018, 560, 255-260. [CrossRef]

50. Gao, M.C.; Ünlü, N.; Shiflet, G.J.; Mihalkovic, M.; Widom, M. Reassessment of Al-Ce and Al-Nd binary systems supported by critical experiments and first-principles energy calculations. Mater. Sci. Eng. A 2005, 36, 3269-3279.

51. Jin, L.; Kevorkov, D.; Medraj, M.; Chartrand, P. Al-Mg-RE (RE = La, Ce, Pr, Nd, Sm) systems: Thermodynamic evaluations and optimizations coupled with key experiments and Miedema's model estimations. J. Chem. Thermodyn. 2013, 58, 166-195. [CrossRef]

52. Kang, Y.B.; Pelton, A.D.; Chartrand, P.; Fuerst, C.D. Critical evaluation and thermodynamic optimization of the Al-Ce, Al-Y, Al-Sc and Mg-Sc binary systems. Calphad 2008, 32, 413-422. [CrossRef]

53. Coury, F.G.; Pires, E.L.; Wolf, W.; de Almeida, F.H.; e Silva, A.L.; Botta, W.J.; Kiminami, C.S.; Kaufman, M.J. Insight into the complex ternary phase behavior in Al-Mn-Ce alloys. J. Alloys Compd. 2017, 727, 460-468. [CrossRef]

54. Plotkowski, A.; Sisco, K.; Bahl, S.; Shyam, A.; Yang, Y.; Allard, L.; Nandwana, P.; Rossy, A.M.; Dehoff, R.R. Microstructure and properties of a high temperature Al-Ce-Mn alloy produced by additive manufacturing. Acta Mater. 2020, 196, 595-608. [CrossRef]

55. Yang, Q.; Lv, S.H.; Meng, F.Z.; Guan, K.; Li, B.S.; Zhang, X.H.; Zhang, J.Q.; Liu, X.J.; Meng, J. Detailed Structures and Formation Mechanisms of Well-Known $\mathrm{Al}_{10} \mathrm{RE}_{2} \mathrm{Mn}_{7}$ Phase in Die-Cast Mg-4Al-4RE-0.3Mn Alloy. Acta Metall. Sin. (Engl. Lett.) 2019, 32, 178-186. [CrossRef]

56. Clark, S.J.; Segall, M.D.; Pickard, C.J.; Hasnip, P.J.; Probert, M.I.; Refson, K.; Payne, M.C. First principles methods using CASTEP. Z Krist-Cryst Mater. 2005, 220, 567-570.

57. Ding, W.J.; Yi, J.X.; Chen, P.; Li, D.L.; Peng, L.M.; Tang, B.Y. Elastic properties and electronic structures of typical Al-Ce structures from first-principles calculations. Solid State Sci. 2012, 14, 555-561. [CrossRef]

58. Zhou, D.; Peng, P.; Hu, Y.; Liu, J. Study on structural stability of Mg-Ce intermetallic compounds based on the pseudopotential plane-wave method. Rare Met. Mater. Eng. 2006, 35, 871.

59. Kang, Y.B.; Jin, L.L.; Chartrand, P.; Gheribi, A.; Bai, K.; Wu, P. Thermodynamic evaluations and optimizations of binary Mg-light rare Earth (La, Ce, Pr, Nd, Sm) systems. Calphad 2012, 38, 100-116. [CrossRef]

60. Zeng, M.X.; Wang, R.N.; Tang, B.Y.; Peng, L.M.; Ding, W.J. Elastic and electronic properties of tI26-type Mg12 $R E(R E=C e, P r$ and Nd) phases. Modell. Simul. Mater. Sci. Eng. 2012, 20, 035018.

61. Zhou, D.W.; Peng, P.; Liu, J.S. Electronic structure and stability of Mg-Ce intermetallic compounds from first-principles calculations. J. Alloys Compd. 2007, 428, 316-321. [CrossRef]

62. Gao, M.C.; Ünlü, N.; Mihalkovic, M.; Widom, M.; Shiflet, G.J. Glass formation, phase equilibria, and thermodynamic assessment of the Al-Ce-Co system assisted by first-principles energy calculations. Metall. Mater. Trans. A 2007, 38, 2540-2551. [CrossRef]

63. Czerwinski, F.; Shalchi Amirkhiz, B. On the $\mathrm{Al}_{-} \mathrm{Al}_{11} \mathrm{Ce}_{3}$ Eutectic Transformation in Aluminum-Cerium Binary Alloys. Materials 2020, 13, 4549. [CrossRef]

64. Pauling, L.C. A resonating-valence-bond theory of metals and intermetallic compounds. Proc. R. Soc. Lond. Ser. A 1949, 196, 343-362.

65. Huang, W.; Ma, N.; Ma, Y.; Amaishi, T.; Takada, K.; Hama, T. Material Model Development of Magnesium Alloy and Its Strength Evaluation. Materials 2021, 14, 454. [PubMed]

66. Indhiarto, I.; Shimizu, T.; Yang, M. Effect of Peak Current Density on Tensile Properties of AZ31B Magnesium Alloy. Materials 2021, 14, 1457. [CrossRef]

67. Merson, D.; Brilevsky, A.; Myagkikh, P.; Tarkova, A.; Prokhorikhin, A.; Kretov, E.; Frolova, T.; Vinogradov, A. The Functional Properties of Mg-Zn-X Biodegradable Magnesium Alloys. Materials 2020, 13, 544. [CrossRef] [PubMed]

68. Bramfitt, B.L. The effect of carbide and nitride additions on the heterogeneous nucleation behavior of liquid iron. Metall. Trans. 1970, 1, 1987-1995.

69. Coury, F.G.; Botta, W.J.; Bolfarini, C.; Kiminami, C.S.; Kaufman, M.J. Reassessment of the effects of Ce on quasicrystal formation and microstructural evolution in rapidly solidified Al-Mn alloys. Acta Mater. 2015, 98, 221-228. [CrossRef]

70. Yang, Y.; Bahl, S.; Sisco, K.; Lance, M.; Shin, D.; Shyam, A.; Plotkowski, A.; Dehoff, R.R. Primary solidification of ternary compounds in Al-rich Al-Ce-Mn alloys. J. Alloys Compd. 2020, 844, 156048. [CrossRef] 